\title{
Mercury and Organic Carbon Dynamics During Runoff Episodes from a Northeastern USA Watershed
}

\author{
P. F. Schuster $\cdot$ J. B. Shanley • \\ M. Marvin-Dipasquale • M. M. Reddy • \\ G. R. Aiken - D. A. Roth $\cdot$ H. E. Taylor • \\ D. P. Krabbenhoft • J. F. DeWild
}

Received: 16 February 2007 / Accepted: 18 August 2007 / Published online: 12 October 2007

(C) Springer Science + Business Media B.V. 2007

\begin{abstract}
Mercury and organic carbon concentrations vary dynamically in streamwater at the Sleepers River Research Watershed in Vermont, USA. Total mercury (THg) concentrations ranged from 0.53 to $93.8 \mathrm{ng} / \mathrm{L}$ during a 3-year period of study. The highest mercury ( $\mathrm{Hg})$ concentrations occurred slightly before peak flows and were associated with the highest organic carbon (OC) concentrations. Dissolved $\mathrm{Hg}(\mathrm{DHg})$ was the dominant form in the upland catchments; particulate $\mathrm{Hg}(\mathrm{PHg})$ dominated in the lowland catchments. The concentration of hydrophobic acid (HPOA), the
\end{abstract}

P. F. Schuster $(\bowtie) \cdot$ M. M. Reddy $\cdot$ G. R. Aiken

D. A. Roth $\cdot$ H. E. Taylor

U.S. Geological Survey,

3215 Marine Street, Suite E-127,

Boulder, CO 80303, USA

e-mail: pschuste@usgs.gov

J. B. Shanley

U.S. Geological Survey,

P.O. Box 628, Montpelier, VT 05601, USA

M. Marvin-Dipasquale

U.S. Geological Survey,

345 Middlefield Road,

Menlo Park, CA 94025, USA

D. P. Krabbenhoft $\cdot$ J. F. DeWild

U.S. Geological Survey,

8505 Research Way,

Middleton, WI 53562, USA major component of dissolved organic carbon (DOC), explained $41-98 \%$ of the variability of $\mathrm{DHg}$ concentration while DOC flux explained $68-85 \%$ of the variability in $\mathrm{DHg}$ flux, indicating both quality and quantity of the DOC substantially influenced the transport and fate of DHg. Particulate organic carbon (POC) concentrations explained 50\% of the $\mathrm{PHg}$ variability, indicating that $\mathrm{POC}$ is an important transport mechanism for $\mathrm{PHg}$. Despite available sources of DHg and wetlands in the upland catchments, dissolved methylmercury (DmeHg) concentrations in streamwaters were below detection limit (0.04 ng/L). PHg and particulate methylmercury ( $\mathrm{PmeHg})$ had a strong positive correlation $\left(r^{2}=0.84\right.$, $p<0.0001$ ), suggesting a common source; likely instream or near-stream POC eroded or re-suspended during spring snowmelt and summer storms. Ratios of $\mathrm{PmeHg}$ to $\mathrm{THg}$ were low and fairly constant despite an apparent higher methylmercury (meHg) production potential in the summer. Methylmercury production in soils and stream sediments was below detection during snowmelt in April and highest in stream sediments (compared to forest and wetland soils) sampled in July. Using the watershed approach, the correlation of the percent of wetland cover to $\mathrm{TmeHg}$ concentrations in streamwater indicates that poorly drained wetland soils are a source of $\mathrm{meHg}$ and the relatively high concentrations found in stream surface sediments in July indicate these zones are a meHg sink. 
Keywords Mercury · Dissolved mercury ·

Particulate mercury $\cdot$ Methylmercury .

Dissolved methylmercury .

Particulate methylmercury - Organic carbon .

Dissolved organic carbon - Particulate organic carbon .

Hydrophobic organic acid - Watershed - Catchment .

Streamwater · Snowmelt · Sleepers River · Vermont

\section{Introduction}

Atmospheric deposition of total mercury (THg), and subsequent mercury methylation, is widely recognized as originating from mostly anthropogenic sources that have exceeded natural inputs since the onset of the industrial period (Fitzgerald et al. 1998). The transport and fate of this deposition as a toxic contaminant to aquatic and terrestrial food webs is a longstanding and critical global environmental issue (Morel et al. 1998). In forested areas, atmospheric deposition of $\mathrm{THg}$ to soils is in the forms of precipitation, throughfall, dry deposition, and litterfall. While some THg may be revolatilized, a major export mechanism of $\mathrm{THg}$ from the watershed is particle-associated $\mathrm{THg}$ transported by streamwater (Grigal 2002).

To effectively mitigate ecological consequences of $\mathrm{Hg}$ contamination, an understanding of $\mathrm{Hg}$ cycling at the watershed scale is needed. The watershed or catchment approach provides datasets that can potentially describe high spatial and temporal variability in the dynamics of $\mathrm{Hg}-\mathrm{OC}$ relations. Of particular interest are the chemical dynamics during high flow periods such as spring snowmelt or summer storms. These periods can represent a significant portion of the annual water and chemical flux from a watershed.

It is generally accepted among researchers that inorganic divalent mercury $(\mathrm{Hg}(\mathrm{II}))$ and $\mathrm{Hg}$ (II) complexes (hereafter referred to as $\mathrm{Hg}(\mathrm{II})$ ) are the predominant forms of $\mathrm{Hg}$ in soils and surface water (Skyllberg et al. 2000; Grigal 2002). In the absence of DOC and sulfide, mercury complexes to form $\mathrm{HgOH}^{+}$ and $\mathrm{HgCl}^{1+}$ in most natural surface waters. However, many surface waters contain substantial amounts of DOC and possibly sulfide (depending on redox conditions). If sulfide is present, then the dominant $\mathrm{Hg}$ complex is hydrogen sulfide $\left(\mathrm{S}^{-}\right)$. If sulfide is absent, the dominant $\mathrm{Hg}$ complex is $\mathrm{Hg}-\mathrm{DOC}$ (Benoit et al. 2001a; Haitzer et al. 2002; Reddy and Aiken
2001; Gilmour et al. 1998). A number of studies have shown that $\mathrm{Hg}$ transport through a watershed is generally associated with the movement of organic matter (OM) in both dissolved and particulate form (Shanley et al. 1999; Hurley et al. 1998; Driscoll et al. 1995). Although dissolved OM competes with sulfide for mercury binding (Ravichandran 2004), the presence of reduced sulfur sites within natural $\mathrm{OM}$ has been suggested as largely responsible for the strong binding of $\mathrm{Hg}$ to $\mathrm{OM}$ and facilitates the transport of dissolved $\mathrm{Hg}$ in natural waters (Haitzer et al. 2002; Skyllberg et al. 2003). Thus, a low-sulfide aquatic environment with dissolved organic matter (DOM) enriched in reduced sulfur functional groups would be conducive to complexation of $\mathrm{Hg}$ to DOM (Skyllberg et al. 2003; Benoit et al. 2001a).

Results presented here are from 3 consecutive years (2000-2002) of $\mathrm{Hg}$ investigations at the Sleepers River Research Watershed, Vermont, USA. In the first year of study, observed patterns of mercury and organic carbon dynamics were consistent across a set of 10 forested and agricultural catchments of different size, land cover, and land use (Shanley et al. 2002). This paper reports the findings of two additional years of studies built on these findings using the catchment approach to monitor high-flow dynamics and mercury methylation in uplands. The second year focused on $\mathrm{THg}$ and $\mathrm{OM}$; streamwaters were intensively sampled, along with soils and snowpack during peak snowmelt discharge to better understand processes that affect the interactions of $\mathrm{Hg}$ and OM. During the third year, focus shifted to the study of methylmercury $(\mathrm{meHg})$ concentrations and microbial $\mathrm{meHg}$ production/degradation rate investigations in various sub-habitat types within the watershed.

This study describes the frequency of occurrence and regional distribution of both dissolved and particulate forms of $\mathrm{Hg}$ in a forested New England watershed and evaluates hydrologic conditions influencing $\mathrm{Hg}$ mobilization and transformation linked to organic carbon (OC) quantity and quality. The Sleepers River watershed is considered an end member among research catchments in the New England region because of its well-buffered streamwater (Hornbeck et al. 1997). The average baseflow alkalinity is $60 \mathrm{mg} / \mathrm{L}$ and $\mathrm{pHs}$ are about 7.5 , resulting in circumneutral streamwater that would tend to limit mercury mobility (Driscoll et al. 2003). Thus, the mercury behavior described for the Sleepers 
River watershed could be potentially more dynamic in the more common acidic systems of the northeastern U.S.A.

\section{Site Description}

Sleepers River Research Watershed covers $111 \mathrm{~km}^{2}$ and is comprised of several paired and nested catchments (watersheds) of mixed Northern Hardwood Forest and open agricultural land in northern Vermont, ranging in elevation from 195 to $790 \mathrm{~m}$ above sea level (Fig. 1). Streams range from first to fourth order and are well buffered by carbonates in the bedrock and till, and dominant soils are spodosols and inceptisols. A more detailed description of watershed characteristics is given elsewhere (Shanley and Chalmers 1999; Shanley et al. 2002).

The Sleepers River watershed receives more than $1,000 \mathrm{~mm}$ of precipitation per year, of which approximately $30 \%$ falls as snow. Isotopic evidence indicates that groundwater discharge is the dominant component of streamwater even during the seasonal period of active snowmelt and that groundwater is also a major component of saturated overland flow in the associated riparian areas (Shanley et al. 1995;
McDonnell et al. 1998; McGlynn et al. 1999). About one-half of the annual stream discharge from the watershed occurs during a 6-week snowmelt period from late March to early May (Fig. 2). Sustained high water tables during the snowmelt period cause the flushing of mineral and organic soils and results in more than half of the annual stream-water flux of weathering solutes during the snowmelt period (Peters et al. 2006). Flashy discharge typically occurs during convective summer storms from about June to October (Shanley and Chalmers 1999).

\section{Methods}

Each catchment sampled in the Sleepers River watershed was instrumented with a recording stream gauge which provided continuous discharge records during the period of study. For the water years 2000 2002, water and sediment samples were collected at 10 sites over the periods of spring snowmelt and one summer rain event (September 15, 2002; Fig. 2) at the outlets of selected catchments, snowpits, and surface soils within the watershed (Fig. 1). Sampling frequencies of surface waters were dictated by logistics; generally, attempts were made to sample as many
Fig. 1 Location of sampling sites within catchments of the Sleepers River Research Watershed, Vermont

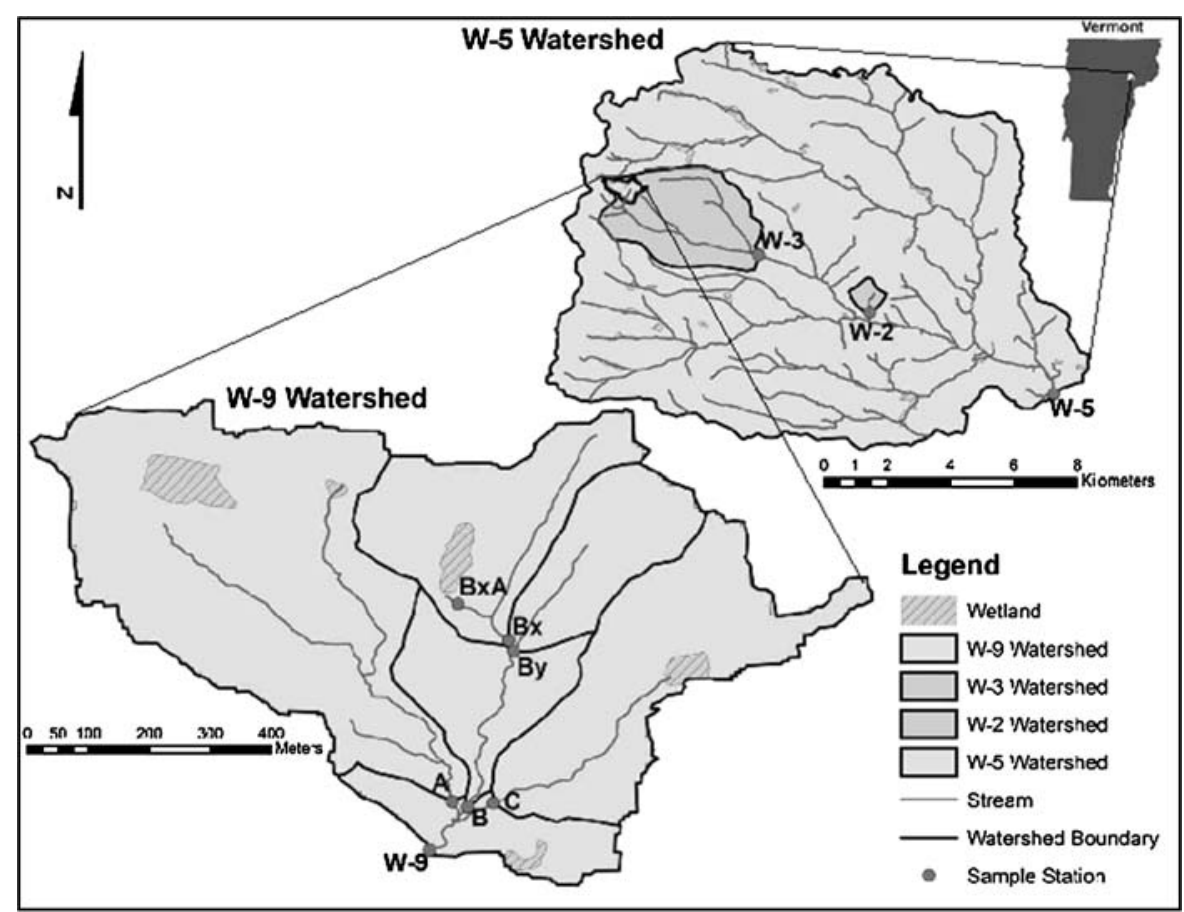




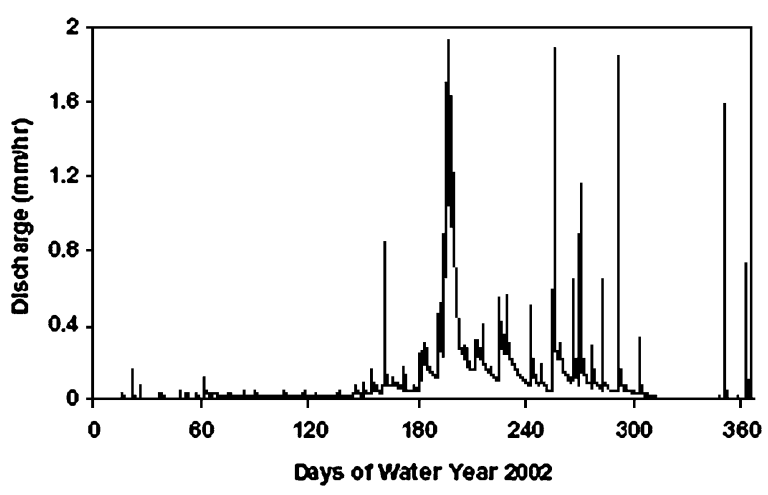

Fig. 2 Hydrograph for the W-9 catchment for water year (WY) 2002. Water year is defined as October 1 to September 30; mm/ $\mathrm{hr}$, millimeters per hour

sites as possible at the highest frequencies at peak flows, regardless of time of day. Surface water samples were collected according to established USGS protocols (Wilde et al. 1998) and appropriate clean techniques were used for collection of lowconcentration analytes (Horowitz et al. 1994), including the use of particle-free plastic gloves, acid-cleaned 1-L Teflon ${ }^{1}$ bottles (for $\mathrm{Hg}$ ) and pre-combusted glass amber bottles (for DOC). Water was collected in the centroid of stream flow after which the samples were transported to an on-site lab for initial processing, typically within $4 \mathrm{~h}$ of collection. Subsequently, samples were stored and chilled until further analysis.

Suspended sediment was collected on glass fiber filters and analyzed for sediment and particulate carbon (PC) concentrations (USEPA 1997. Method No. 440.0). Generally, it is assumed that particulate inorganic carbon (PIC) is negligible compared to particulate organic carbon (POC) (Keefe 1994). PIC was determined on four samples from different streams during the 2003 snowmelt; 0.6, 2.0, 3.3, and $13.8 \%$ of PC (Shanley and Chalmers, USGS, written commun.), thus PC was assumed to represent particulate organic carbon (POC) on all samples.

Snowpack samples also were collected at 10 sites within the W-9 catchment (not shown in Fig. 1) during the spring of 2001 about 2 weeks before stream flows began to rise in response to the melting snowpack. Clean-hands protocols and a Lexan ${ }^{\mathrm{TM}}$ shovel were used to sample ten open-face pits which were dug down to the soil surface throughout the

\footnotetext{
${ }^{1}$ The use of brand, trade ${ }^{\mathrm{TM}}$, or firm names in this report is for identification purposes only and does not constitute endorsement by the U.S. Geological Survey.
}

watershed. A clean face was exposed and, using a Teflon scoop, the snow was sampled from the top to the bottom of the pit. A depth-integrated sample was collected from the face of the snowpit (snowpits ranged from 50 to $100 \mathrm{~cm}$ ) and was placed in a Teflon bag and sent frozen to the USGS laboratory in Boulder, Colorado, where it was stored frozen until processing and analysis of dissolved (filtered) mercury (DHg) and particulate mercury (PHg).

Samples of the surface soil (O-horizon) were collected at 28 locations within the W-9 catchment (not shown in Fig. 1). Using a stainless steel spoon and clean-hands protocol, soil was scraped and placed into 40-mL baked, amber glass vials with Teflon lined caps. Samples were stored frozen until processing and analysis (USEPA 1994).

Six soil and stream sediment samples were collected in three "zones" (stream, riparian, and wetland) within the W-9 catchment during the April 2002 spring snowmelt and again in July 2003; at shallow $(0-4 \mathrm{~cm})$ depth during the 2002 sampling and both shallow $(0-4 \mathrm{~cm})$ and deep (variable, averaging $20 \mathrm{~cm}$ ) intervals during 2003. Stream surface sediments were collected from the weir pools upstream from W-9 (April) or W-9BY (July), corresponding riparian sediments were collected just upstream of each stream site, and wetland soils were collected (July only) in the W-9BXA catchment (Fig. 1). These samples were brought to the laboratory and incubated for determination of $\mathrm{meHg}$ production potential and degradation potential rates using ${ }^{203} \mathrm{Hg}$ (II) and ${ }^{14} \mathrm{CH}_{3} \mathrm{HgI}$ radiotracer amendments, respectively (Marvin-DiPasquale and Agee 2003). The July samples were also measured for $\mathrm{THg}$ and total methylmercury ( $\mathrm{TmeHg})$.

Table 1 provides a definition of the numerous abbreviations used throughout this paper. Quality assurance and a detailed description of analytical methods for major ions, DOC, POC, DHg, $\mathrm{PHg}$, dissolved methylmercury (DmeHg), particulate methylmercury (PmeHg), and trace metals are described in the Appendix.

\section{Results and Discussion}

During three consecutive snowmelt seasons (20002002) and a single summer rain event, THg concentrations in streamwater from nine selected catchments 
Table 1 Definitions of abbreviations for mercury and organic matter and carbon species described in this study

\begin{tabular}{|c|c|c|c|}
\hline \multicolumn{2}{|c|}{ Mercury species } & \multicolumn{2}{|c|}{ Organic species } \\
\hline Abbreviation & Name & Abbreviation & Name \\
\hline $\mathrm{Hg}$ & Mercury & DOM & Dissolved organic matter \\
\hline $\mathrm{Hg}(\mathrm{II})$ & Inorganic divalent mercury & $\mathrm{PC}$ & Particulate carbon \\
\hline $\mathrm{THg}$ & Total mercury & $\mathrm{OC}$ & Organic carbon \\
\hline $\mathrm{DHg}$ & Dissolved mercury & TOC & Total organic carbon \\
\hline $\mathrm{PHg}$ & Particulate mercury & DOC & Dissolved organic carbon \\
\hline $\mathrm{meHg}$ & methylmercury & POC & Particulate organic carbon \\
\hline TmeHg & Total methylmercury & HPOA & Hydrophobic acid \\
\hline DmeHg & Dissolved methylmercury & & \\
\hline $\mathrm{PmeHg}$ & Particulate methylmercury & & \\
\hline SmeHg & Sediment methylmercury & & \\
\hline
\end{tabular}

and the outlet of the Sleepers River watershed were very similar in median and range of concentrations (Fig. 3a). The summer storm, however, ranged more than two orders of magnitude with a median concentration more than five times the 3-year median for snowmelt. The lowest streamwater $\mathrm{Hg}$ concentrations occurred at base flow prior to snowmelt. The highest $\mathrm{Hg}$ concentrations occurred during high-flow episodes (generally peaking slightly before peak discharge) and were always associated with the highest dissolved and particulate organic carbon concentrations.

\subsection{Mercury-Carbon Dynamics}

Similar to findings from numerous other studies (Shanley et al. 1999, 2002; Hurley et al. 1998; Driscoll et al. 1995; Krabbenhoft et al. 1995; Maurice-Bourgoin et al. 2003; Balogh et al. 2000; Cowell et al. 1995), results from surface water sampling during three consecutive snowmelt seasons (2000-2002) showed a positive correlation between DHg and DOC (Fig. 4a); there is also a significant positive correlation between $\mathrm{PHg}$ and POC and both relations persisted even when the data from all ten streams of diverse watershed characteristics were pooled together (Fig. 4b). A summary of correlations among the dissolved and particulate phases of organic carbon and mercury are given in Table 2. Correlation coefficients are given for individual catchments in a single year and also for pooled catchments during the 3-year study. The pooled results contain outliers within the datasets, thus both the standard Pearson linear regression and the Spearman rank regression were calculated (McCall 1986). The Spearman rank regression improved the correlations among the dissolved and particulate phases of organic carbon and mercury by 12 and $30 \%$, respectively.

Because about half of the annual Sleepers River streamflow results from the spring snowmelt occurring in a 6-week period, an understanding of the snowmelt hydrology is critical to the understanding of the transport and fate of $\mathrm{Hg}$ in the watershed. $\mathrm{THg}$ concentrations (the sum of DHg and PHg) measured in snowpack averaged $8 \mathrm{ng} / \mathrm{L}$, about two times higher than average $\mathrm{THg}$ streamwater concentrations. THg concentrations measured from 28 soil samples collected in close proximity to W-9 averaged $180 \mathrm{ng} / \mathrm{g}$ (Shanley, USGS, written commun.). This compares well to other surface soils with similar characteristics in the region (170-300 ng/g) (Shanley et al. 1999). These data suggest that both snowpack and surface soils provide sources of $\mathrm{Hg}$ (II) to the streams and for potential meHg production.

The highest concentrations of $\mathrm{THg}$ and $\mathrm{POC}$ generally occur days before peak snowmelt discharge. Bishop and others (1995b) have suggested that "old water" may be a source of mercury to streams where overland flow in a catchment is rare. This is not the case at Sleepers River where overland flow is commonly observed. During winter, soil frost does not develop in saturated areas or areas of groundwater discharge. In drier areas, however, soil frost generally develops before the winter snowpack is established. Once the snowpack reaches a depth of about $60 \mathrm{~cm}$, heat from the ground begins to melt the frost upward toward the land surface (Shanley and Chalmers 1999). Later in the winter, the base of the snowpack also begins to melt (Stewart Clark, USGS, written commun.). This process speeds the melting of the snowpack in the spring often resulting in overland 
Fig. 3 Box plots of a total mercury (THg), b dissolved mercury (DHg), c particulate mercury $(\mathrm{PHg}), \mathbf{d}$ total methylmercury $(\mathrm{TmeHg}), \mathbf{e}$ dissolved organic carbon (DOC), and $\mathbf{f}$ particulate organic carbon (POC). $m g / L$ milligrams per liter, $n g / L$ nanograms per liter. Data from all catchments were compiled and grouped by water year and source. The sample population is shown above each box
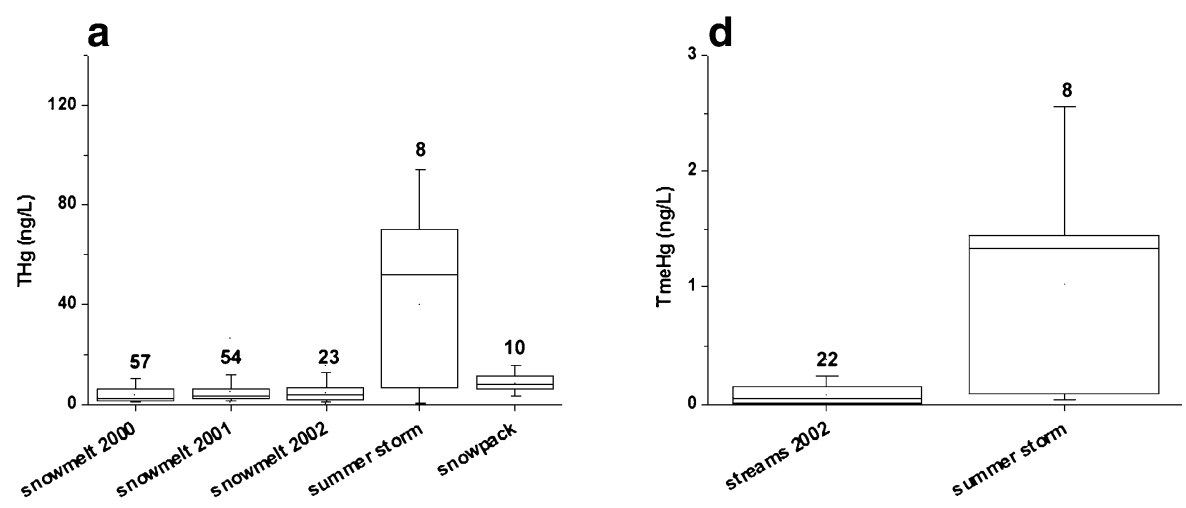

b
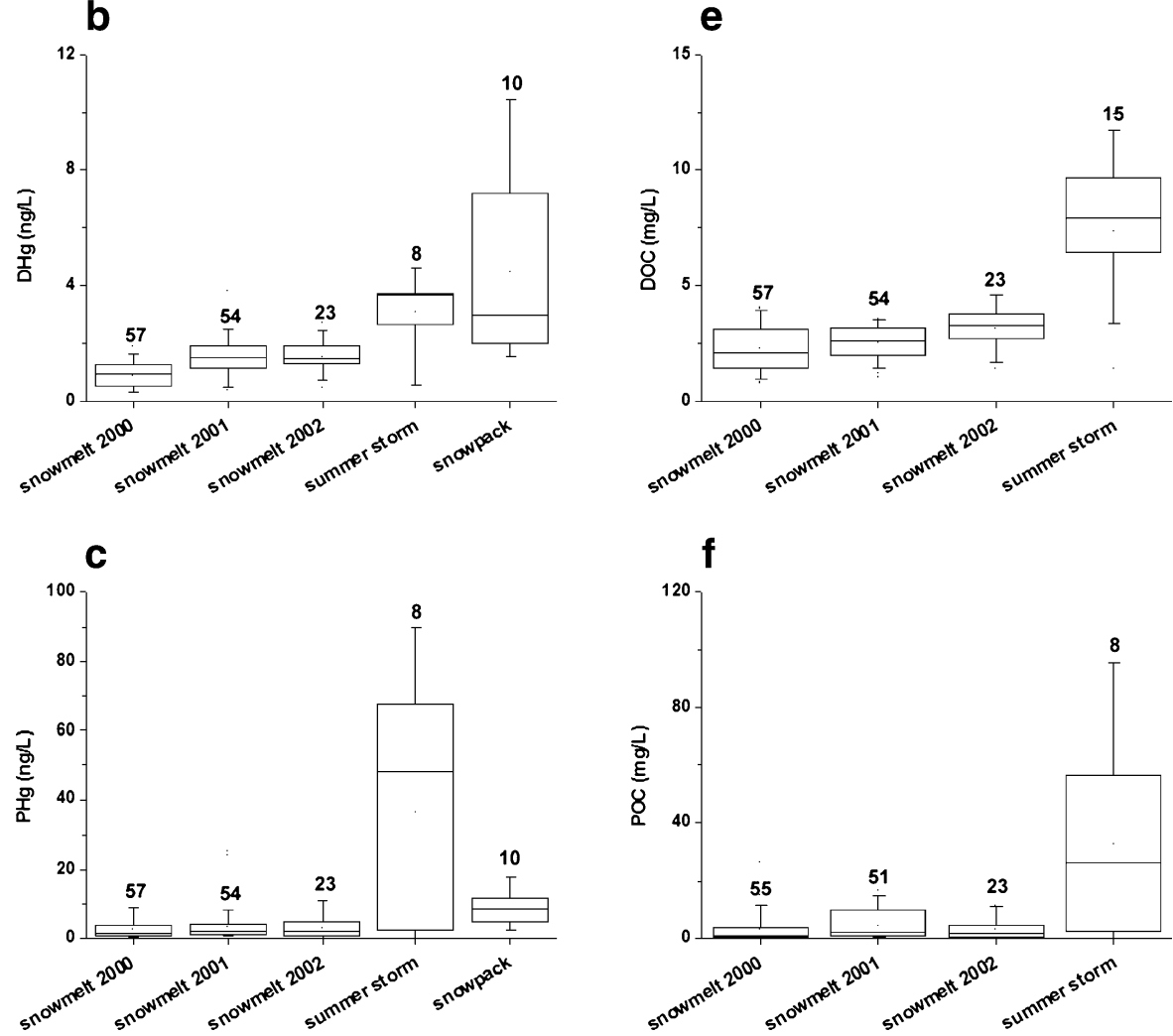

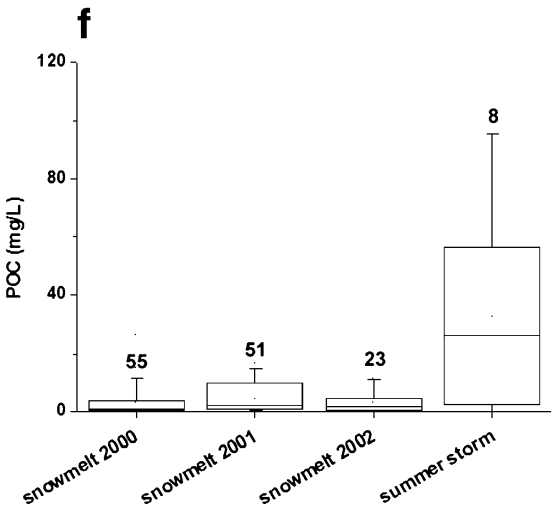

flow in many areas. Snowmelt with elevated THg concentrations infiltrates the thawed surface soil. The surface soil also is enriched in $\mathrm{THg}$ from dry deposition and litterfall prior to snowpack development (Rasmussen 1995) and DOC from litterfall decomposition and degradation (Hongve 1999). Clockwise hysteresis in the riparian groundwaterstreamflow relation (McDonnell et al. 1998) (water table is closer to the surface for a given flow on the rising limb of the hydrograph compared to the same flow on the falling limb) suggests that near-stream saturation excess overland flow drives the hydrograph rise during early snowmelt. This overland flow is enriched in $\mathrm{THg}$, explaining why $\mathrm{THg}$ generally peaks just prior to snowmelt discharge peaks. Thus, it appears that the dynamics of the $\mathrm{Hg}$-enriched melting snowpack over Hg- and organic-enriched surface soils is an important controlling factor in the timing of peak $\mathrm{Hg}$ fluxes from a northern forested watershed, emphasizing the importance of sampling streams prior to peak discharge to accurately measure peak fluxes of $\mathrm{Hg}$.

The DHg-DOC relation for interflow (subsurface flow with sustained soil contact) from numerous studies 

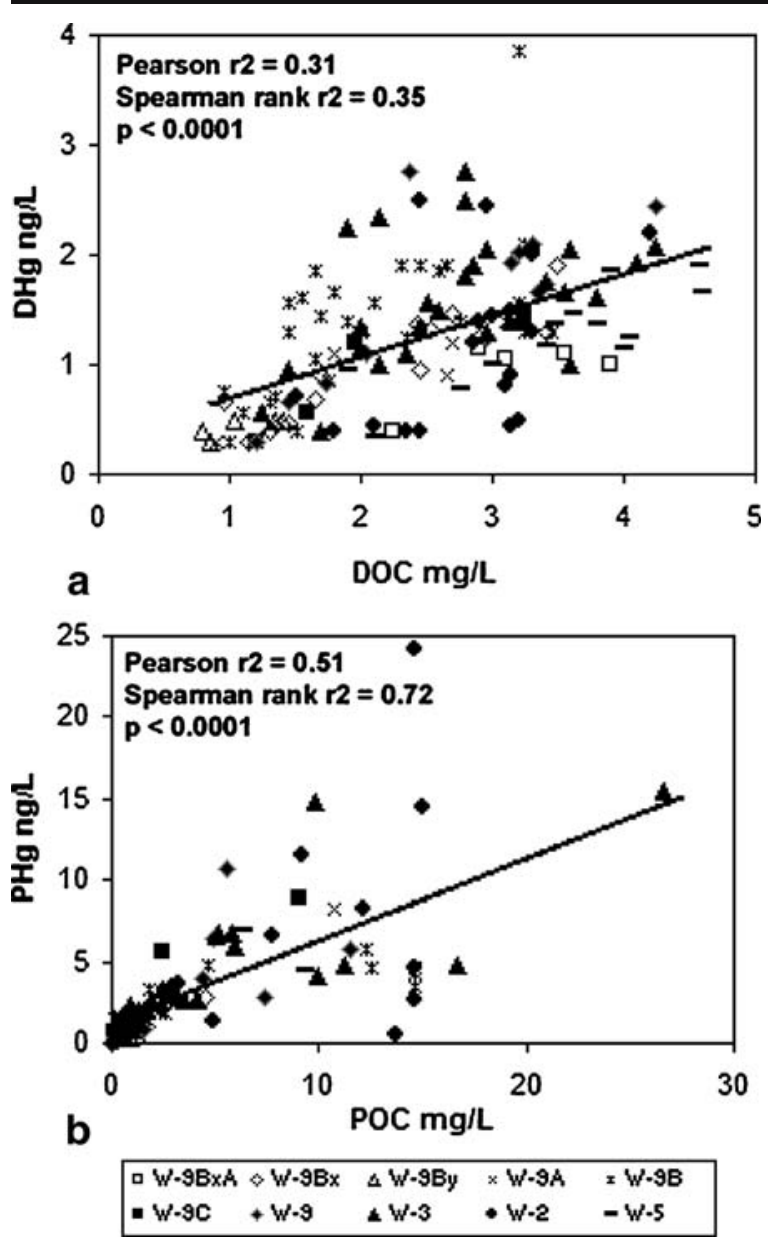

Fig. 4 a Dissolved organic carbon (DOC) vs dissolved mercury (DHg), and b particulate organic carbon (POC) vs total particulate mercury $(\mathrm{PHg})$ for 10 catchments in the Sleepers River Watershed during snowmelt (all catchments sampled in 2000, W-9B, W-2, W-3 sampled in 2001, W-9BX, W-9, W-3, W-5 sampled in 2002). Modified from Shanley et al. 2002. ng/L, nanograms per liter; mg/L, milligrams per liter

in the Northern Hemisphere (Grigal 2002) has a slope similar to that for the Sleepers River streamwater (about $0.4 \mathrm{ng} \mathrm{Hg}$ per $1 \mathrm{mg}$ DOC) (Fig. 4a). Conversely, Grigal (2002) also summarized that the $\mathrm{DHg}$ intercept at zero DOC is $11-13 \mathrm{ng} / \mathrm{L}$ for interflow. Although the sorptive properties of the surface soils are likely to influence the amount of DHg in stream waters (Ussiri and Johnson 2004), the intercept for Sleepers River streamwater is very near zero (0.3) DHg, suggesting that the sources of $\mathrm{DHg}$ during the spring snowmelt flush in the upland catchments of the watershed originate largely from saturated overland flow, i.e. precipitation (rain and snowmelt) reaching the stream with minimal soil contact.
Dissolved organic carbon was characterized in selected stream-water samples from the 2001 snowmelt season. The character of DOC is determined by a combination of an aquatic system's hydrology and biological characteristics. Specific ultraviolet absorbance (SUVA, described in the Appendix) is an indicator of the character or quality of the DOC and a proxy measurement of the aromaticity or "reactiveness" with chemical species (Weishaar et al. 2003). The SUVA results indicate that the DOC in the streamwater becomes more aromatic with increasing discharge during the snowmelt season (approximately 0.007 per $\mathrm{mm} / \mathrm{h}$ of discharge) (Fig. 5). However, the relation between SUVA and DHg is poor $\left(r^{2}=0.07\right)$, suggesting that DOC amount or flux, driven by discharge, is the important factor in the transport and fate of $\mathrm{DHg}$ in these surface waters, and that DOC character or quality likely plays a lesser role.

In an attempt to further understand the significance of these factors, DOC was fractionated on 10 streamwater samples from catchments W-9B, W-2, and W-3 during the 2001 snowmelt season. Other northeastern streams and lakes are primarily dominated by the hydrophobic acid fraction (HPOA) of DOC (David and Vance 1991; Moore 2003. This is also the case in the Sleepers River watershed; the HPOA isolate was the major component of the total DOC (median value $50 \%$, range $30-60 \%$ ) and its fraction percent of the total DOC had a strong positive correlation to DOC concentration $\left(r^{2}>0.85\right)$; similar to other systems (Mattsson et al. 1998). The relation between $\mathrm{DHg}$ and the concentration of HPOA was statistically significant $\left(r^{2}=0.55, p=0.01\right.$ for all data points) (Fig. 6a). Benoit et al. (2001a) showed that DOM isolates (e.g. HPOA) are stronger ligands for $\mathrm{Hg}$ than chloride or EDTA. It is difficult to separate the effects of DOC quality and flux on the transport and fate of Hg. Fleck (1999) showed that there is no significant correlation of HPOA to $\mathrm{THg}$ in streamwater and that this is likely due to small changes in DOC quality being dwarfed or masked by a large change in flux. Figure 6 suggests that, although the HPOA fraction may possess chemical qualities (i.e. the abundance of reduced sulfur sites) influencing the transport and fate of DHg in the watershed, there are likely other factors involved. Figure $6 \mathrm{~b}$ shows that DOC flux explains $70 \%$ of the DHg flux variability. Although the quality of the DOC likely plays an important role in the flux of $\mathrm{DHg}$ from catchments within the Sleepers River 
Table 2 Linear regression coefficients $\left(r^{2}\right)$ for the dissolved and particulate phases of organic carbon and mercury

\begin{tabular}{|c|c|c|c|c|c|c|c|}
\hline \multirow[t]{2}{*}{ Catchment } & \multirow[t]{2}{*}{ Area (ha) } & \multicolumn{3}{|c|}{ DOC-DHg r ${ }^{2} / n$} & \multicolumn{3}{|c|}{ POC-PHg r r/n } \\
\hline & & 2000 & 2001 & 2002 & 2000 & 2001 & 2002 \\
\hline W-9BXA & 2 & $0.48 / 5$ & $\mathrm{Na}$ & $\mathrm{Na}$ & $0.98 / 5$ & $\mathrm{Na}$ & $\mathrm{Na}$ \\
\hline W-9BY & 3 & $0.60 / 5$ & $\mathrm{Na}$ & $\mathrm{Na}$ & $0.49 / 5$ & $\mathrm{Na}$ & $\mathrm{Na}$ \\
\hline W-9BX & 5 & $0.78 / 6$ & $\mathrm{Na}$ & $0.92 / 8$ & $0.97 / 6$ & $\mathrm{Na}$ & $0.94 / 7$ \\
\hline W-9C & 8 & $0.84 / 5$ & $\mathrm{Na}$ & $\mathrm{Na}$ & $0.89 / 5$ & $\mathrm{Na}$ & $\mathrm{Na}$ \\
\hline W-9B & 13 & $0.56 / 11$ & $0.31 / 20$ & $\mathrm{Na}$ & $0.82 / 10$ & $0.83 / 19$ & $\mathrm{Na}$ \\
\hline W-9A & 17 & $0.71 / 5$ & $\mathrm{Na}$ & $\mathrm{Na}$ & $0.97 / 5$ & $\mathrm{Na}$ & $\mathrm{Na}$ \\
\hline W-9 & 41 & $0.92 / 5$ & $\mathrm{Na}$ & $0.26 / 7$ & $0.90 / 5$ & $\mathrm{Na}$ & $0.41 / 7$ \\
\hline W-2 & 59 & $0.65 / 4$ & $0.22 / 7$ & $\mathrm{Na}$ & $0.97 / 4$ & $0.27 / 17$ & $\mathrm{Na}$ \\
\hline $\mathrm{W}-3$ & 836 & $0.57 / 5$ & $0.08 / 22$ & $\mathrm{Na}$ & $0.99 / 5$ & $0.08 / 20$ & $\mathrm{Na}$ \\
\hline W-5 & 11,125 & $0.53 / 6$ & $\mathrm{Na}$ & $0.88 / 7$ & $0.63 / 5$ & $\mathrm{Na}$ & $0.59 / 7$ \\
\hline \multirow[t]{2}{*}{ ALL } & $\mathrm{Na}$ & Pearson & & Spearman & Pearson & & Spearman \\
\hline & & $0.31 / 133$ & & $0.35 / 133$ & $0.51 / 128$ & & $0.72 / 128$ \\
\hline
\end{tabular}

Results for each catchment are listed by study year along with a summary of the pooled results (ALL), which compares the standard Pearson linear regression to the Spearman rank correlation regression.

DOC Dissolved organic carbon, $P O C$ particulate organic carbon, $\mathrm{DHg}$ dissolved mercury, $\mathrm{PHg}$ particulate mercury, $n$ number of samples, $\mathrm{Na}$ not available, $h a$ hectare

watershed, the flux of DOC, driven by discharge, appears to be the dominant control.

\subsection{The Importance of Particulate Organic Carbon in the Transport of Mercury}

Mercury transport by particulates has been shown to dominate the THg flux in some watersheds (Aastrup and Johnson 1991; Scherbatskoy et al. 1998). Flowweighted averages of the relative contribution of $\mathrm{PHg}$ to $\mathrm{THg}$ during peak snowmelt showed that $\mathrm{PHg}$ systematically increased from slightly more than $40 \%$ in the upland catchments to about $80 \%$ at W-5, the outlet of the watershed (Fig. 7a), becoming the dominant form of $\mathrm{Hg}$. Similarly, flow-weighted averages of the relative contribution of POC to total organic carbon (TOC) during peak snowmelt showed that POC also generally increased from the upland catchments to the watershed outlet at W-5 (Fig. 7b), becoming the dominant form of TOC. The systematic increase of $\mathrm{PHg}$ and $\mathrm{POC}$ indicates that dissolved phases of $\mathrm{Hg}$ and $\mathrm{OC}$ dominate the upland or headwater areas and particulate phases of $\mathrm{Hg}$ and OC dominate in the lower reaches of the Sleepers River watershed.

During peak flow, on average, about $30 \%$ of the total suspended sediment at Sleepers River was organic matter. Similar to other findings, $\mathrm{PHg}$ was highly
Fig. 5 Variation of SUVA with discharge in the Sleepers River Watershed. Data are compiled from all 3 water years. Stream discharge normalized to millimeters per hour $(\mathrm{mm} / \mathrm{h})$. The inset is a plot of the quartile medians of discharge vs SUVA showing a clear positive correlation; SUVA Specific ultraviolet (UV) absorbance defined as UV absorbance at 254 nanometer wavelength/ dissolved organic carbon concentration

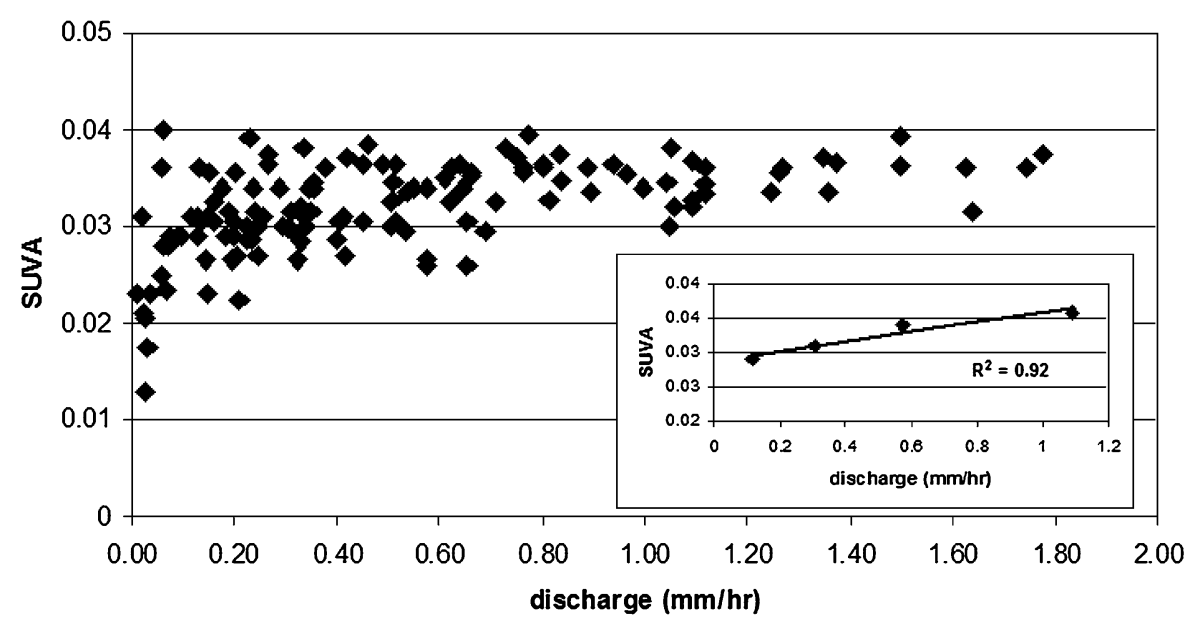



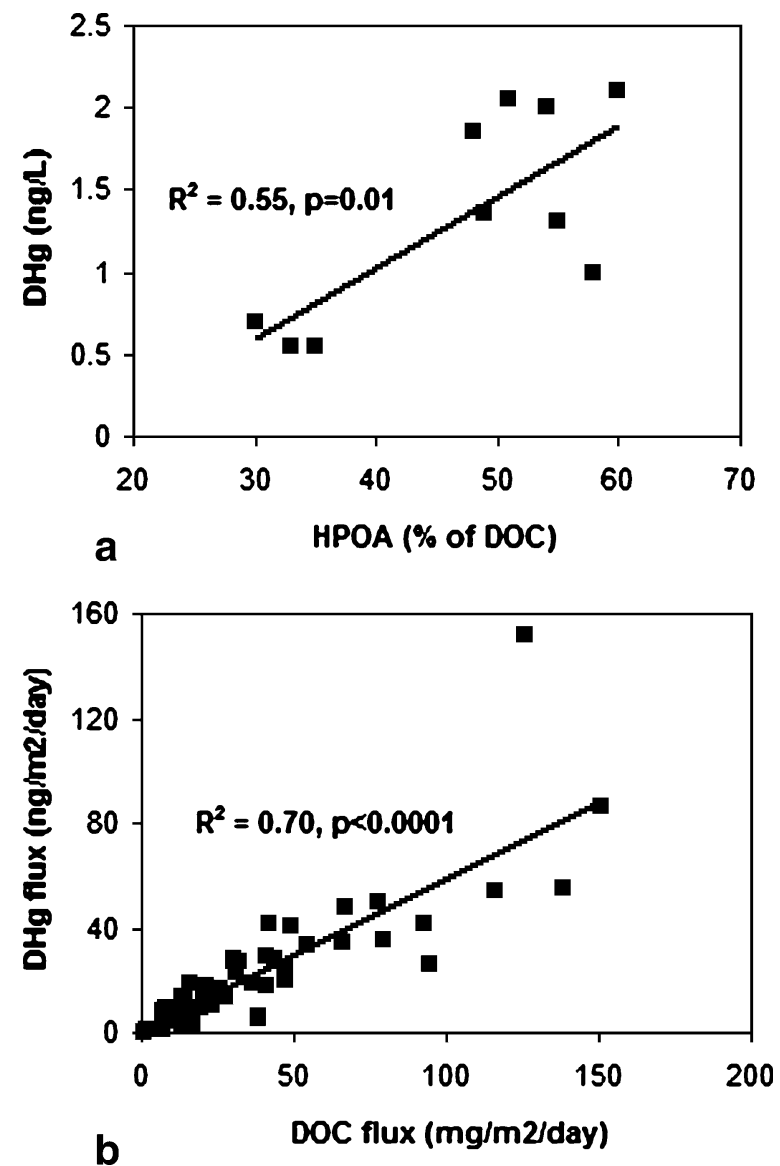

Fig. 6 Catchments W-9B, W-2, and W-3 during snowmelt 2001, a concentration of hydrophobic acid fraction (HPOA) of the dissolved organic carbon (DOC) vs dissolved mercury (DHg), b Instantaneous flux of DOC vs flux of DHg. $\mathrm{mg} / \mathrm{m} 2$ / day millgrams per meter squared per day, $n g / m 2 /$ day nanograms per meter squared per day

correlated with the organic fraction of suspended sediment (POC) suggesting $\mathrm{Hg}$ is associated with or bound to POC. Regression statistics compiled from all catchments for the 3-year study indicate a significant linear correlation $\left(r^{2}=0.50, p<0.001\right)$, greater than that of the DHg-DOC correlation (Fig. $4 \mathrm{~b}$ ). Figure 8 is typical of all the catchments studied in the Sleepers River watershed, showing a more detailed look at the PHg-POC relation during the 2001 spring snowmelt at W-9B. Particulate mercury and POC are the predominant forms of $\mathrm{THg}$ and TOC (the sum of DOC and POC measurements), respectively.

Particulate mercury and POC fluxes were calculated during the snowmelt peak for the W-5 outlet (2002) and a baseflow flux was extrapolated for the remainder of the year using an average of $\mathrm{PHg}$ and $\mathrm{POC}$
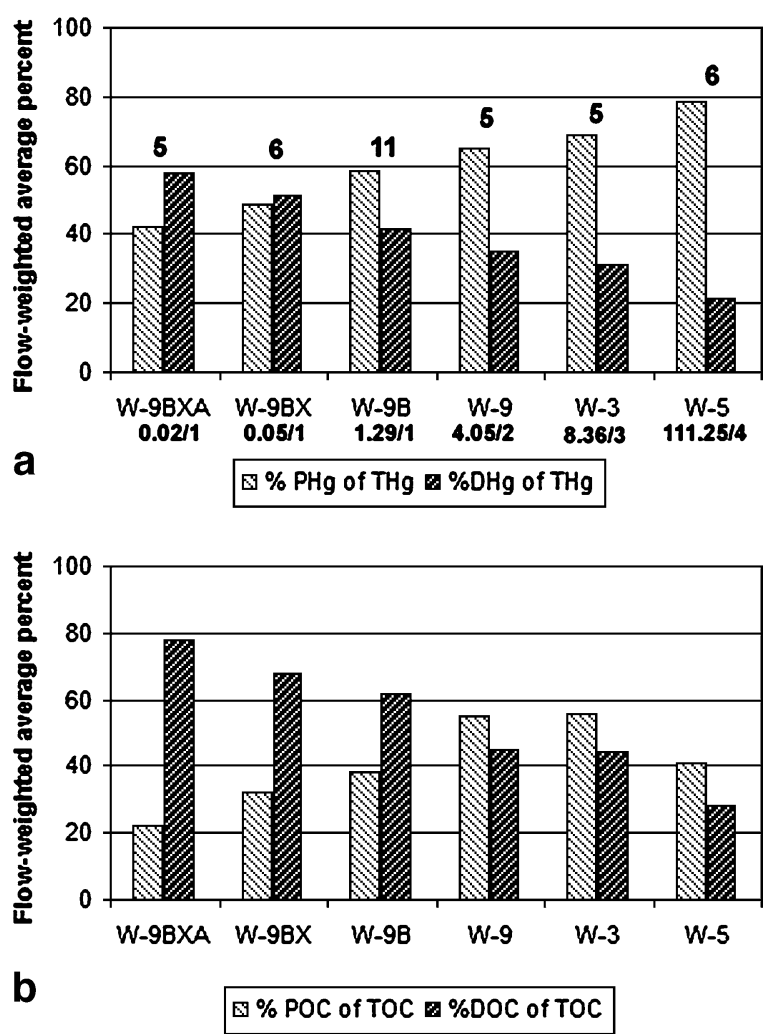

Fig. 7 Catchments W-9B, W-2, and W-3 during snowmelt 2000, a Flow-weighted average percent of particulate total mecury $(\mathrm{PHg})$ and dissolved mercury $(\mathrm{DHg})$ to total mecury $(\mathrm{THg})$, b Flow-weighted average percent of particulate organic carbon (POC) and dissolved organic carbon (DOC) to total organic carbon (TOC). Organized by increasing drainage area and stream order; from left to right, drainage areas $\left(\mathrm{km}^{2}\right) /$ stream order are shown below the catchment ID, number of samples are shown above each bar. Drainage areas, stream orders, and number of samples are the same for panels $\mathbf{a}$ and $\mathbf{b}$

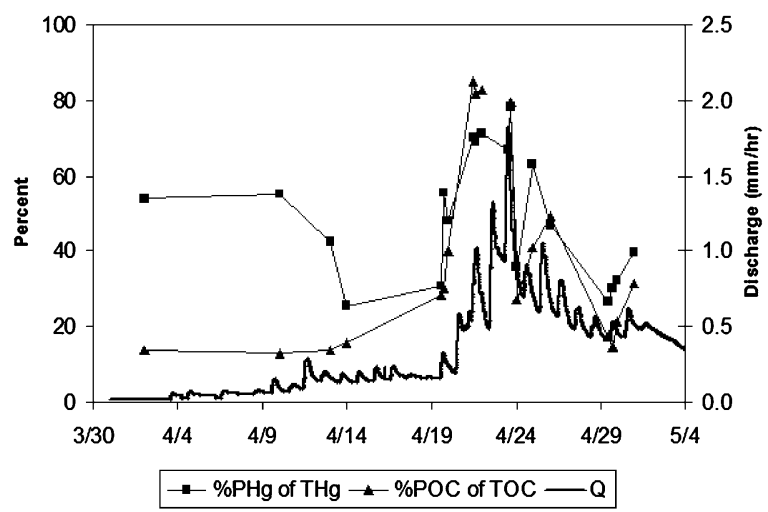

Fig. 8 Percent of particulate mercury $(\mathrm{PHg})$ to total mercury (THg) and percent of particulate organic carbon (POC) to total organic carbon (TOC) peaking 4 days before peak snowmelt discharge $(Q)$ during 2002 at catchment W-9B during the 2001 snowmelt. $\mathrm{mm} / \mathrm{hr}$ millimeters per hour 
measurements taken during early spring (2000-2002) prior to increasing streamwater flows due to snowmelt $(n=11)$. Approximately $50 \%$ of the total annual $\mathrm{PHg}$ flux and $75 \%$ of the total annual POC flux at W-5 occurred during the 3-week snowmelt peak which accounted for about one quarter of the annual stream discharge (these estimates are probably low because summer storms were not measured). These data demonstrate the importance of POC, which is at its greatest concentrations during peak flows, as a transport mechanism for $\mathrm{PHg}$ from a catchment.

\subsection{The Importance of Summer Storms on the Transport of Mercury}

Another important $\mathrm{Hg}$ transport mechanism from a catchment may be summer storms, especially when preceded by a prolonged dry period. In September, 2002, an exceptionally dry summer was followed by an intense summer storm or rewetting event $(51 \mathrm{~mm}$ of rain in $1 \mathrm{~h}$ ) (Fig. 2). The streamwater was intensely sampled during this event ( 7 samples in a 4-h period). Similar to mercury-carbon dynamics during snowmelt, $\mathrm{THg}$ concentrations rose very rapidly prior to peak discharge. Total mercury $(\mathrm{THg}$ ) ranged from $0.6 \mathrm{ng} / \mathrm{L}$ (at a pre-event base flow) to $94 \mathrm{ng} / \mathrm{L}$ (one of the highest concentrations reported for a relatively pristine stream) and POC ranged from 0.06 to $96 \mathrm{mg} / \mathrm{L}$ (Fig. 3). Comparatively, Bishop et al. (1995a), measured THg in the range of only 3-7 ng/L and TOC in the range of $30-40 \mathrm{mg} / \mathrm{L}$ during a summer storm in Sweden. The median and 3rd quartile concentrations of $\mathrm{THg}$ for the summer storm were five times greater than the snowmelt medians and third quartiles; POC medians for the storm were 30 times that of the snowmelt medians.

In the context of the watershed hydrology, the storm represented $1 \%$ of the annual water flux from $\mathrm{W}-9$. The relative importance of summer storms versus snowmelt was determined by comparing the flux of $\mathrm{THg}$ from the storm to an equivalent time during peak snowmelt. The duration of the summer storm was about $2 \mathrm{~h}$. The total flux of THg from W-9 was determined for the summer storm and an equivalent time during peak snowmelt. The total flux for the storm was about $10 \%$ greater than the total flux of the snowmelt at peak flow for an equivalent time, suggesting that, although the storm is of short duration, its impact on the flux of $\mathrm{Hg}$ from the watershed is equal to or greater than the flux from peak snowmelt for equal time periods.

Comparing the slope (0.35) and intercept $(0.58)$ of the DOC-DHg relation during this summer storm to the data summarized by Grigal (2002), suggests that the sources of DHg are both interflow and overland flow. Because it would be expected that a short, intense rain event would result mostly in overland flow to the streams, overland flow is the likely source of the very high POC values measured during this storm. The slope of the DOC-DHg relation suggests, however, that there is also a component of interflow as a source of DHg. Fleck (1999) showed that the HPOA fraction of DOC dominates in interflow and is positively correlated to $\mathrm{THg}$ and Fig. 6 shows a significant correlation of HPOA to $\mathrm{DHg}$. Although the patterns observed in this rewetting event further demonstrate the important role of $\mathrm{POC}$ in $\mathrm{Hg}$ transport from a catchment, an elevated HPOA component of the DOC from interflow may also play a role. Moreover, the elevated $\mathrm{THg}$ concentrations measured during this event suggest that stored pools of $\mathrm{Hg}$ are being released due to the mobilization of large amounts of POC and that storms are an important mechanism in the mobilization and export of $\mathrm{Hg}$ from a watershed.

\subsection{Methylmercury}

Total methylmercury (TmeHg) concentrations in streamwater during the 2002 snowmelt were extremely low $(<0.04$ to $0.39 \mathrm{ng} / \mathrm{L})$, with almost all of the export of TmeHg occurring as PmeHg $(>0.45 \mu \mathrm{m})$ during highflow periods, regardless of landscape type (Shanley et al. 2002) within the watershed; DmeHg was generally below detection limit $(0.04 \mathrm{ng} / \mathrm{L})$. TmeHg in the rewetting event ranged from 0.04 to $2.56 \mathrm{ng} / \mathrm{L}$ with some of the highest $\mathrm{TmeHg}$ concentrations reported for relatively pristine streamwaters (Fig. 3d). Similar to $\mathrm{THg}$, the highest concentrations of TmeHg occurred during high flows in association with elevated POC.

Despite the presence of wetlands and mucky soils in the watershed, an average of only about $2 \%$ of $\mathrm{PHg}$ occurred as PmeHg (Fig. 9a). THg and PmeHg were positively correlated (Fig. 9b), suggesting a common source; likely in-stream or near-stream OM eroded or re-suspended during spring snowmelt or summer storms. The linked behavior of $\mathrm{THg}$ and $\mathrm{TmeHg}$ at 

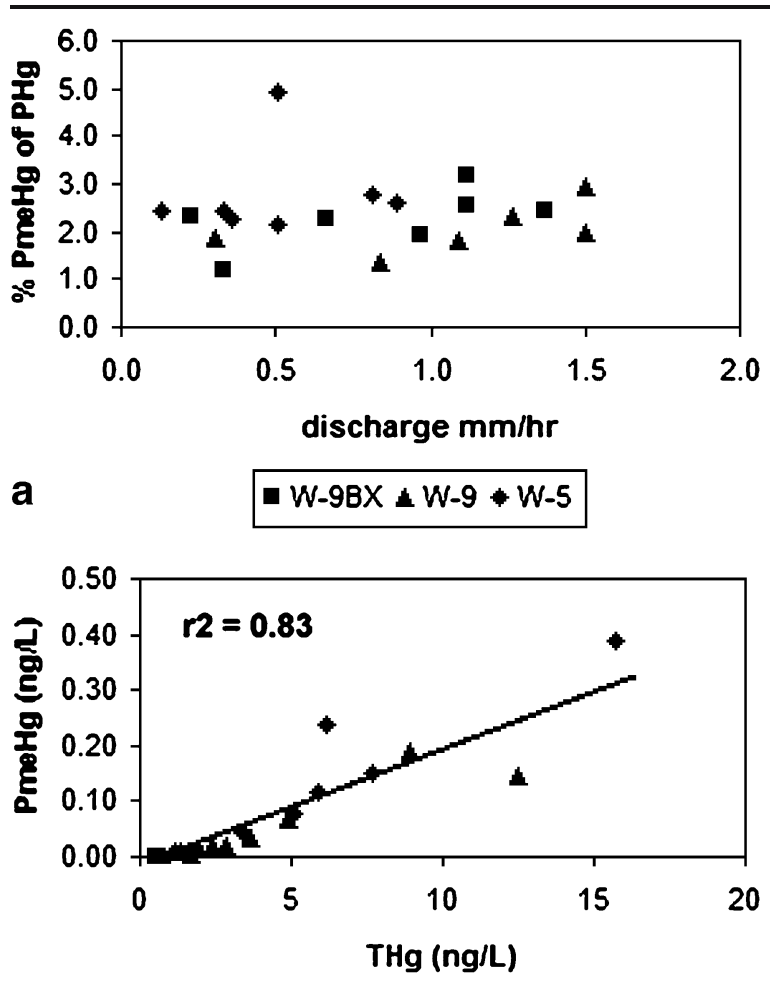

b
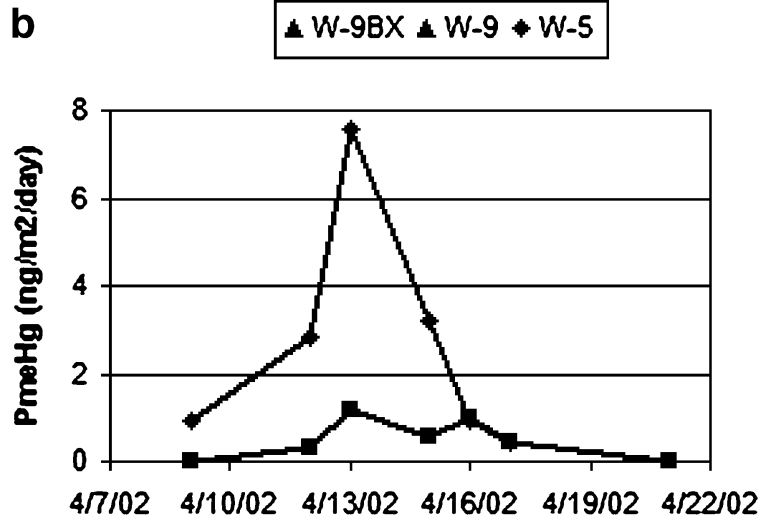

C

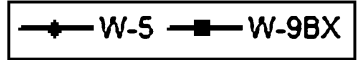

Fig. 9 a Percent of particulate methylmercury (PmeHg) to total mercury (THg) vs discharge during spring snowmelt 2002 for upland (W-9BX, W-9) and lowland (W-5) catchments, b $\mathrm{PmeHg}$ vs $\mathrm{THg}$ for the same catchments and same year. c A comparison of the fluxes of $\mathrm{PmeHg}$ from the upland catchment W-9BX and the lowland catchment W-5. $\mathrm{mm} / \mathrm{h}$, millimeters per hour, $n g / m 2 /$ day nanograns per square meter per day

Sleepers River differs from that in Scandinavian catchments (Bishop et al. 1995a,b,c; Lee et al. 1995a,b; Munthe et al. 1995) where an inverse correlation suggests $\mathrm{THg}$ and $\mathrm{TmeHg}$ are decoupled

(THg increases but $\mathrm{TmeHg}$ dilutes with increasing flow). The decoupling of $\mathrm{THg}$ and $\mathrm{TmeHg}$ observed in Scandinavian streams argues for a groundwater source of meHg while $\mathrm{Hg}$ is delivered via surficial pathways that flush the organic soils.

When considering meHg production in a catchment, wetland density is considered to be the most important factor (Hurley et al. 1995; Krabbenhoft et al. 1995). It is generally thought that most of the meHg in a catchment is likely produced in zones that have anoxic conditions but also have concentrations of sulfide that are optimal for mercury methylation (Lee et al. 1995a, 2000; Bishop et al. 1995b; Benoit et al. 2001b, 2003; Schwesig et al. 1999; Gilmour et al. 1998). Despite a decrease in the wetland cover (calculated from mucky soil types) from about $5 \%$ for the upland catchment W-9BX $\left(0.05 \mathrm{~km}^{2}\right)$ to about $1 \%$ for the Sleepers River watershed (W-5) $\left(111 \mathrm{~km}^{2}\right)$, there is a 10 -fold and 7-fold increase in the instantaneous flux of PmeHg and POC, respectively, at peak flow during spring snowmelt. These results indicate that increases in POC at peak snowmelt, likely mobilized by overland flow, dominates the flux of PmeHg from the watershed and the percent of wetland cover in a catchment plays a lesser role. In addition, the flux of $\mathrm{PmeHg}$ from W-9BX to W-5 increases more than sevenfold (Fig. 9c), suggesting that methylation must also be occurring in riparian zones or stream channel sediments and that this process is resulting in an increase in $\mathrm{meHg}$ concentrations along the stream reach.

Maximum concentrations of $\mathrm{TmeHg}$ during the rewetting event $(2.56 \mathrm{ng} / \mathrm{L})$ were nearly three times higher then the maximum concentrations measured during three snowmelt seasons (Fig. 3d), and also those reported by Bishop et al. (1995a), again demonstrating the importance of sampling summer storms to assess the flux of $\mathrm{meHg}$ from a catchment. Similar to relations observed in spring snowmelt, TmeHg also tracked $\mathrm{THg}$ and POC, again suggesting the sources of mercury are common, originating from stream and riparian sediments.

\subsection{Methylmercury Production and Degradation Potentials}

The magnitude of methylation and/or demethylation of mercury can be highly variable among and within 


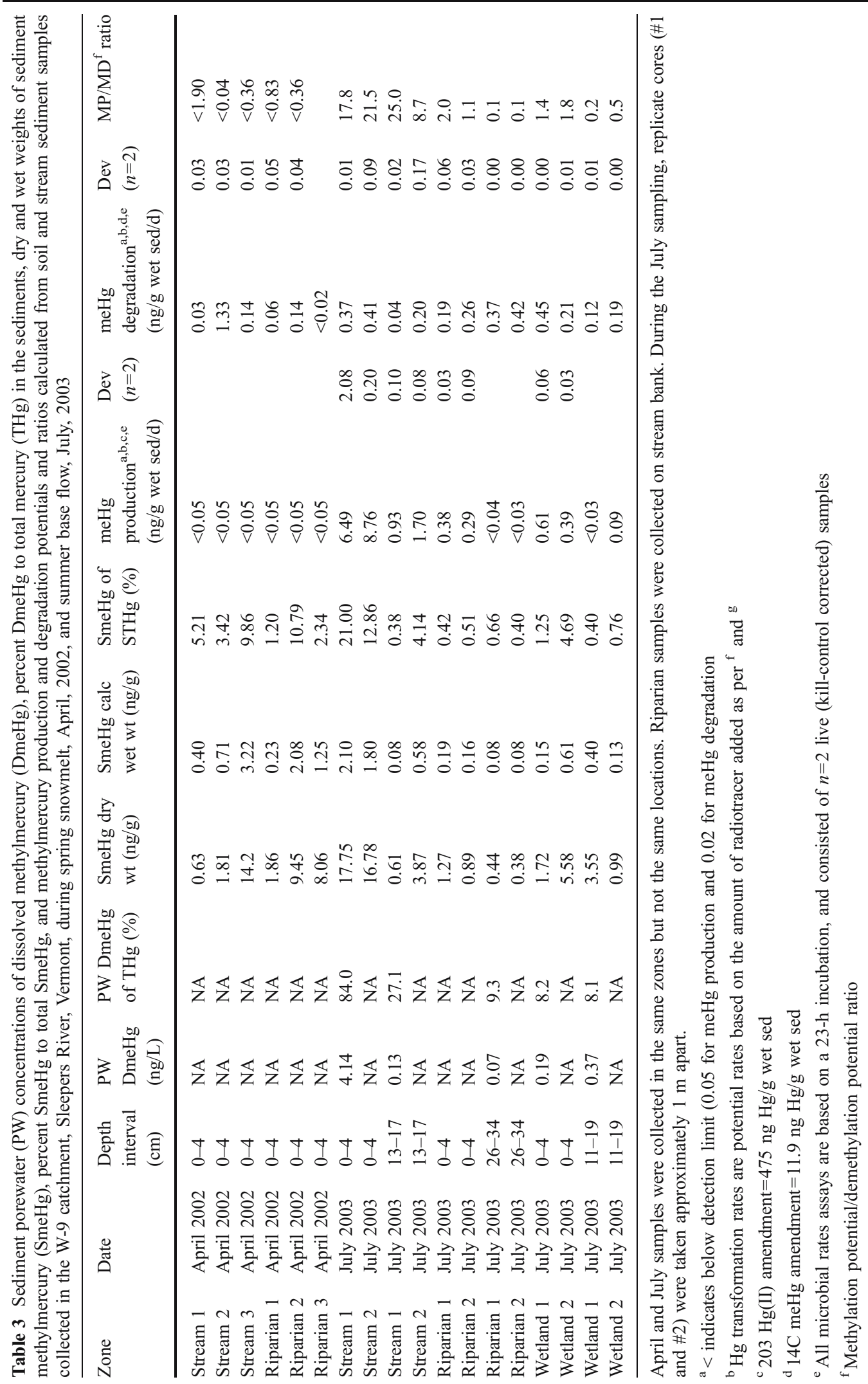


aquatic systems. There are several variables important to the meHg production-degradation potentials of a watershed. First, there must be a source of mercury to the system; at Sleepers River, atmospheric deposition (of which most is dry deposition) is likely the dominant source (Shanley et al. 1999). Moreover, the percent of $\mathrm{DHg}$ to $\mathrm{THg}$ is highest in the upland catchments (Fig. 3), consistent with the highest density of wetlands. Second, there are four important sources of meHg; precipitation, runoff from wetlands, in-lake methylation (Rudd 1995), and in-stream methylation. Methylmercury concentrations in precipitation are generally minimal in this region (0.03$0.05 \mathrm{ng} / \mathrm{L})$ (Sakamoto et al. 2001; Allan et al. 2001) and there are no lakes in the Sleepers River watershed. There are, however, several upland wetlands and stream sediment zones that could be conducive to $\mathrm{Hg}$ methylation. Third, there are several key biogeochemical processes that are of great importance to the in situ methylation-demethylation of mercury; anoxic conditions, seasonal variation (although it is unclear at this time how temperature affects mercury methylation), the presence of sulfate-reducing bacteria, and the ambient concentrations of sulfide and sulfate. It is important to note that net $\mathrm{meHg}$ production is generally greatest when and where both meHg degradation rates and reduced sulfur concentrations are low (Marvin-DiPasquale and Agee 2003).

Methylmercury production and degradation potentials were measured in the sediments of three catchment "zones" defined here as stream, riparian, and wetland (Tables 3 and 4). During April, meHg production potential was below the detection limit of $0.05 \mathrm{ng} / \mathrm{g}$ wet sed/day for both the stream and riparian sites at the incubation temperature of $4^{\circ} \mathrm{C}$ (under snowpack conditions). This was primarily due to highly oxidized sediment and soil conditions ( +368 to $+526 \mathrm{mv}$ ) (Table 4) resulting from oxygen-rich melting snowpack. The oxygen-rich snowmelt infuses the surface soil horizons leading to oxic conditions not conducive to anaerbic bacteria that carry out $\mathrm{Hg}$ (II)-methylation (Benoit et al. 2001a,b) as evidenced by sulfate reduction rates at or near the detection limit (Table 4). Measurements of $\mathrm{Fe}(\mathrm{II})$ were below the detection limit further indicating oxic conditions. Moreover, meHg degradation potential rates were comparatively active

Table 4 Field and lab measurements of temperature, $\mathrm{pH}$, and other key parameters used to assess the reducing conditions of each zone sampled in the W-9 catchment, Sleepers River, Vermont

\begin{tabular}{|c|c|c|c|c|c|c|c|c|c|c|c|c|}
\hline \multirow[t]{2}{*}{ Zone } & \multirow[t]{2}{*}{ Date } & \multirow{2}{*}{$\begin{array}{l}\text { Depth } \\
\text { interval } \\
(\mathrm{cm})\end{array}$} & \multicolumn{2}{|c|}{ Temp $\left({ }^{\circ} \mathrm{C}\right)$} & \multicolumn{2}{|l|}{$\mathrm{pH}$} & \multicolumn{2}{|c|}{$\begin{array}{l}\text { Redox } \\
{[\mathrm{Eh}(\mathrm{mV})]}\end{array}$} & \multicolumn{3}{|c|}{ Pore water } & \multirow{2}{*}{$\begin{array}{l}\text { Sulfate reduction } \\
\text { rate }\left(\mathrm{pmol} / \mathrm{cm}^{3}\right. \\
\text { wet } \mathrm{sed} / \mathrm{d})\end{array}$} \\
\hline & & & Field & Lab & Field & $\mathrm{Lab}$ & Field & $\mathrm{Lab}$ & $\begin{array}{l}\mathrm{Fe}(\mathrm{II}) \\
(\mathrm{mg} / \mathrm{L})\end{array}$ & $\begin{array}{l}\text { Sulfate } \\
(\text { umol/L) }\end{array}$ & $\begin{array}{l}\text { Sulfide } \\
\text { (umol/L) }\end{array}$ & \\
\hline Stream 1 & April 2002 & $0-4$ & 4.2 & $2-4$ & 6.65 & 7.31 & +398 & +368 & $<0.2$ & 80 & NA & $<2$ \\
\hline Stream 2 & April 2002 & $0-4$ & 5.3 & $2-4$ & 7.61 & 7.42 & +528 & +528 & $<0.1$ & 45 & NA & 2 \\
\hline Stream 3 & April 2002 & $0-4$ & 4.6 & $2-4$ & 7.35 & 7.18 & +475 & +475 & 0.2 & 75 & NA & 5 \\
\hline Riparian 1 & April 2002 & $0-4$ & 0.2 & $2-4$ & $4.64-6.45$ & 6.20 & +526 & +526 & $<0.2$ & 56 & NA & $<2$ \\
\hline Riparian 2 & April 2002 & $0-4$ & 0.5 & $2-4$ & 6.54 & 6.55 & +510 & +510 & $<0.2$ & 69 & NA & 3 \\
\hline Riparian 3 & April 2002 & $0-4$ & 3.0 & $2-4$ & 6.07 & 5.92 & +550 & +550 & 0.4 & 73 & NA & $<2$ \\
\hline Stream 1 & July 2003 & $0-4$ & 11.7 & 21 & 6.57 & 6.55 & +3 & -58 & 1.0 & 34 & 0.56 & 123 \\
\hline Stream 2 & July 2003 & $0-4$ & 14.4 & 21 & 7.00 & 6.51 & -15 & -52 & 0.9 & 27 & 1.09 & 779 \\
\hline Stream 1 & July 2003 & $13-17$ & 13.9 & 21 & 6.44 & 6.15 & -78 & -68 & 1.0 & 23 & 3.12 & $<102$ \\
\hline Stream 2 & July 2003 & $13-17$ & 15.0 & 21 & 6.39 & 6.40 & -81 & -78 & 0.5 & 141 & 9.36 & 1534 \\
\hline Riparian 1 & July 2003 & $0-4$ & 14.4 & 21 & 6.54 & 6.01 & +485 & +566 & 0.7 & 48 & 0.00 & 676 \\
\hline Riparian 2 & July 2003 & $0-4$ & 14.4 & 22 & 6.61 & 5.75 & +462 & +498 & 0.9 & 38 & 1.39 & 893 \\
\hline Riparian 1 & July 2003 & $26-34$ & 11.7 & 21 & 6.41 & 6.01 & -45 & +67 & 0.4 & 81 & 0.45 & 780 \\
\hline Riparian 2 & July 2003 & $26-34$ & 11.1 & 21 & 6.13 & 5.74 & -32 & +136 & 0.8 & 49 & 0.46 & 1328 \\
\hline Wetland 1 & July 2003 & $0-4$ & 15.6 & 21 & 6.78 & 7.21 & +238 & +95 & 0.4 & 1 & 1.10 & 334 \\
\hline Wetland 2 & July 2003 & $0-4$ & 15.0 & 21 & 6.96 & 6.46 & +438 & +70 & 3.9 & 4 & 1.17 & 481 \\
\hline Wetland 1 & July 2003 & $11-19$ & 14.4 & 21 & 6.30 & 6.05 & +144 & +463 & 0.1 & $<1$ & 7.42 & 937 \\
\hline Wetland 2 & July 2003 & $11-19$ & 14.4 & 21 & 6.66 & 5.93 & +210 & +356 & 0.1 & 14 & 6.16 & 1533 \\
\hline
\end{tabular}


which accounts for the low net production potential rates. However, there was measurable $\mathrm{meHg}$, albeit small, in the streamwater during spring snowmelt. This meHg may have been produced in the prior growing season and remained in near-stream organic sediment. It is also possible that nutrient-enriched microenvironments with high OM (hot spots relative to surrounding areas) within the forest litter could facilitate limited mercury methylation during snowmelt. Overall, these results suggest there is little net meHg production in surface soils and sediments during April.

Conversely, moderately high meHg production potential rates were observed during the summer (July) despite measurable meHg degradation potential rates (Tables 3 and 4). MeHg production potential rates measured during summer were generally highest in shallow stream sediments, followed by wetland soils, and lowest in adjacent terrestrial riparian soils. Methylation production potential rates decreased with sediment depth in all three sampling zones. The high methylation rate production potentials in the stream sediments are corroborated by the highest measured sediment methymercury (SmeHg) concentrations (16-18 ng/L dry wt) and percent of SmeHg to THg (12-21\%). Moreover, in situ stream sediment redox measurements, sulfate reduction rates, and $\mathrm{Fe}(\mathrm{II})$ concentrations indicate an anoxic environment (Table 4). Although in situ sulfide measurements were highly variable among replicates, elevated sulfide concentrations indicating reduced sulfur conditions do correlate with relatively low meHg production potentials (Marvin-DiPasquale and Agee 2003). It should also be noted that values of $\mathrm{SmeHg}$ are similar in magnitude between April and July, suggesting preservation of the meHg pool. Based on these measurements, it appears that shallow stream sediments develop conditions in July conducive to the methylation of available pools of $\mathrm{Hg}$. This is an important finding considering that the shallow stream sediments are in direct hydrologic connection with the stream water and, subsequently, stream aquatic life.

Acknowledgements We would like to thank Doug Halm and Ann Chalmers of the USGS for their assistance in the field and Kenna Butler, Jennifer L. Agee, Le Kieu, and Hillary A. Harms for their analytical assistance. We would also like to thank Don Campbell and Steffanie Keefe of the USGS for their comments and suggestions.

\section{Appendix}

Water Sample Processing and Analysis

\section{Major anions, DOC, and SUVA}

Samples for major anion and DOC analyses were filtered from the 1-L amber bottles using a $60 \mathrm{~mL}$ Becton Dickinson ${ }^{2}$ plastic syringe with Luer-lok fitting and a $25 \mathrm{~mm}$ Gelman Acrodisk filter with $0.45 \mu \mathrm{m}$ SUPOR $^{\mathrm{TM}}$ membrane (Babiarz et al. 2000) into $40 \mathrm{~mL}$ baked, amber glass vials with Teflon lined caps (DOC) and clean $125 \mathrm{~mL}$ high density polyethylene bottles. All samples were collected in duplicate. The samples were shipped chilled to the USGS research laboratories in Boulder, Colorado.

Major anions were determined by ion chromatography using a Dionex DX120 ion chromatograph ${ }^{\mathrm{TM}}$ (Fishman and Freidman 1989). DOC measurements using the Pt catalysed persulfate wet oxidation method were made on an O.I. Corporation Analytical Model 700 TOC Analyzer ${ }^{\mathrm{TM}}$. A detailed description of the analytical method for DOC is given in Aiken et al. (1992). SUVA, defined as the UV absorbance of a sample measured at a given wavelength divided by the DOC concentration, is an "average" molar absorptivity for all the molecules that comprise the DOC in a water sample. SUVA is, therefore, a parameter that indicates the nature or "quality" of DOC in a given sample and has been used as a surrogate measurement of DOC aromaticity (Chin et al. 1994; Weishaar et al. 2003). SUVA values at $254 \mathrm{~nm}\left(\mathrm{SUVA}_{254}\right)$ are reported in the current work because natural organic matter absorbs strongly at this wavelength, thereby giving increased sensitivity, and because of the strong correlation with the aromatic carbon content of natural organic matter at this wavelength. $\mathrm{SUVA}_{254}$ was determined for each sample in attachment to manuscript this study by dividing the UV absorbance determined at $\lambda=254 \mathrm{~nm}$ by the DOC concentration of the sample. SUVA values are reported in units of $\mathrm{L} /(\mathrm{mg}$ carbon $\times \mathrm{m})$ and have a standard deviation of $\pm 0.1 \mathrm{~L} /(\mathrm{mg}$ carbon $\times \mathrm{cm})$.

\footnotetext{
${ }^{2}$ The use of brand, trade ${ }^{\mathrm{TM}}$, or firm names in this report is for identification purposes only and does not constitute endorsement by the U.S. Geological Survey.
} 


\section{DOC Fractionation}

For DOC fractionation analyses, $3 \mathrm{~L}$ of sample were filtered in the field with Gelman AquaPrep 600 capsule filters $^{\mathrm{TM}}(0.45 \mathrm{um})$ into 1-L, burned, amber glass pesticide bottles with Teflon lined caps. These samples were immediately refrigerated. Samples were shipped chilled overnight to the USGS Boulder laboratory. Samples were refrigerated at the lab and analyzed within 2-weeks of arrival.

DOC fractionation analyses were performed utilizing Amberlite ${ }^{\mathrm{TM}} \mathrm{XAD}$ resins. The DOC present in select samples was chromatographically fractionated into five fractions (hydrophobic neutrals, hydrophobic acids, transphilic neutrals, transphilic acids and hydrophilic organic matter) using XAD-8 and XAD4 resins. The distribution of organic matter in these fractions is a "fingerprint" of DOM in the system and can provide information about how various processes affect the chemistry of the DOM. DOC fractionation is utilized to break the DOC down into groups and determine what mass percent of each group is contained in the overall DOC pool. The XAD-8 resin retains the hydrophobic acid fraction, which is the most aromatic fraction containing the humic and fulvic acids, and the hydrophobic neutrals. The XAD-4 resin retains the transphilic acids and transphilic neutrals, while the XAD-4 effluent contains the low molecular weight hydrophilic acids as well as any other compounds that are not retained by either resin.

The method is a modified version of the XAD- 8 / XAD-4 methods used to isolate organic matter from water samples (Aiken et al. 1992).

\section{Particulate organic carbon (POC)}

This analysis does not distinguish between particulate organic and particulate inorganic carbon of a sample. Many studies have shown that the carbon and nitrogen particulate component is almost entirely organic in natural waters (Keefe 1994). Therefore, it is assumed that the total particulate carbon (TPC) measured in this study occurs as POC. For TPC determinations, filters were sent in duplicate to the Nutrient Analytical Services Laboratory (NASL) at the Chesapeake Bay Laboratories (CBL) for analysis using high temperature combustion where the com- bustion products (water vapor, carbon dioxide and nitrogen gas) are analyzed via a series of thermal conductivity cells and compared to a known standard.

Using a vacuum pump connected to an acrylic filter funnel holder, well-mixed water from a Teflon sample bottle was filtered through a $25 \mathrm{~mm}$ glass fiber filter (GFF) with a nominal pore size of $0.7 \mathrm{um}$. A sufficient volume (50 to $300 \mathrm{~mL}$ ) was filtered to acquire enough material on the filter surface for PC analysis. All samples were collected in duplicate. The filters were folded into aluminum foil and kept chilled until analysis. A complete discussion of quality assurance/quality control procedures can be found at http://cbl.umces.edu/nasl/index.htm.

Dissolved mercury (DHg) and particulate mercury (PHg)

Field seasons 2000 and 2001, collection and processing

The well-mixed sample was filtered through a $0.40 \mu \mathrm{m}$ pore-size Nuclepore polycarbonate membrane filter $^{\mathrm{TM}}$, using a vacuum filter apparatus made from polytetrafloro-ethylene (PTFE) (Kelly and Taylor 1996). The protocol used for the filtration to minimize artifactual contamination included: (1) the filter apparatus was thoroughly cleaned with $1 \% \mathrm{HNO}_{3}$ and rinsed with deionized water; (2) a new $0.40-\mu \mathrm{m}$ pore size, 47-mm-diameter polycarbonate-membrane filter was placed on the filter support and precleaned by drawing $50 \mathrm{~mL}$ of $0.1 \%$ (volume/volume) ultrapure nitric acid rinse solution through the filter into a waste bottle; (3) the filter was then rinsed by drawing $100 \mathrm{~mL}$ of deionized water through it into a waste bottle; (4) about $25 \mathrm{~mL}$ of a subsample of the composite was then filtered to prerinse the $125 \mathrm{~mL}$ acid-rinsed (aquaregia) glass sample receiving bottle and discarded (this step also effectively preloads the filter with particulates); (5) the balance of the subsample was filtered into the sample bottle; and (6) the filtered sample was preserved with the addition of $5 \mathrm{~mL}$ of concentrated ultrapure nitric acid-potassium dichromate solution resulting in a solution of approximately $0.04 \%$ nitric acid-potassium dichromate $/ 4 \%$ nitric acid. Using Teflon ${ }^{\mathrm{TM}_{-}}$-coated tweezers, the filter were placed in acid-rinsed (aquaregia) $60 \mathrm{~mL}$ glass bottles. The same nitric acid-potassium dichromate 
solution $(2.5 \mathrm{~mL})$ was added to leach and preserve the filter sample for analysis of particulate mercury (DHg). Only one filter membrane per sample was used for the entire filtration process. Both $\mathrm{DHg}$ and $\mathrm{PHg}$ samples were collected in duplicate.

\section{Field seasons 2000 and 2001, Laboratory Analysis}

DHg and PHg for the field season 2000 and 2001 were determined at the USGS Research lab in Boulder, Colorado, using an automated cold-vapor atomic fluorescence spectrometer manufactured by PS Analytical $^{\mathrm{TM}}$. Details of the method have been previously described by Roth (1994). Elemental mercury vapor from the sample was produced by chemically reducing mercury in the sample with excess stannous chloride. The resulting vapor was transported to the detector in a stream of argon gas. Peak height intensities of unknown samples were compared to a six-point calibration curve prepared from aqueous standards ranging in concentration from 0 to $50 \mathrm{ng} / \mathrm{L}$. The calibration standards were preserved with the same concentration of $\mathrm{K}_{2} \mathrm{Cr}_{2} \mathrm{O}_{7}$ / $\mathrm{HNO}_{3}$ as the samples.

$\mathrm{DHg}, \mathrm{PHg}$, dissolved methylmercury (DmeHg) and particulate methylmercury (PmeHg)

Field season 2002, collection and processing

An acid-cleaned 1-L Teflon bottle was immersed below the stream-water surface in the centroid of flow, rinsed several times, and filled as described above. Samples were placed on ice and shipped by overnight carrier to the Wisconsin District Mercury $\mathrm{Lab}$ (WDML) for processing. Upon receipt at the WDML, samples were well-mixed and filtered through a $47 \mathrm{~mm}$ diameter quartz fiber filter (QFF) with a nominal pore size of 0.7 um using a vacuum filtration chamber. From each 1-L whole water sample, four samples were collected: filtered total mercury, filtered methyl mercury, particulate total mercury, and particulate methyl mercury. Approximately $500 \mathrm{~mL}$ of sample was filtered, the filtrate collected into a $500 \mathrm{~mL}$ acid-cleaned Teflon bottle, and the filter saved in a Teflon petri dish for subsequent analyses for $\mathrm{DHg}$ and $\mathrm{PHg}$, respectively. The remainder of the sample was filtered and $250 \mathrm{~mL}$ of filtrate was collected into a $250 \mathrm{~mL}$ acid-cleaned Teflon bottle and the filter saved in a Teflon petri dish for subsequent analyses for $\mathrm{DmeHg}$ and $\mathrm{PmeHg}$, respectively. Each Teflon bottle was triple rinsed with small amounts $(\sim 10-20 \mathrm{~mL})$ of filtrate before filling the bottle to the shoulder. The $\mathrm{DHg}$ and $\mathrm{DmeHg}$ samples were preserved with 5 and $2.5 \mathrm{~mL}$ of lowmercury $12 \mathrm{~N} \mathrm{HCl}$, respectively. The particulate samples were frozen until analysis. All sample processing and preservation were performed in the WDML clean lab observing clean hands/dirty hands protocols.

\section{Field season 2002, Laboratory Analysis}

For the field season 2002, DHg, DmeHg, PHg, and $\mathrm{PmeHg}$ were determined at the WDML (USEPA Method 1631 1996; DeWild et al. 2002, 2004; Olson and DeWild 1999; Olund et al. 2004). Analyses for total $\mathrm{Hg}$ were performed with Dual Amalgamation Cold Vapor Atomic Fluorescence Spectrometry (USEPA Method 1631 1996) with slight modifications for particulate analyses http://infotrek.er.usgs.gov/doc/ mercury/methods.html). A bromine monochloride $(\mathrm{BrCl})$ solution were added to the water samples to oxidize all mercury in the sample to $\mathrm{Hg}$ (II). After the addition of the $\mathrm{BrCl}$, the samples were placed in a $50^{\circ} \mathrm{C}$ oven for a minimum of 3 days to insure complete oxidation. When samples were highly stained or contain large amounts of organic carbon they were first placed near a UV source until they became colorless. Just prior to analysis, a small amount of $\mathrm{NH}_{2} \mathrm{OH}-\mathrm{HCl}$ was added to the sample to destroy free halogens. An aliquot of sample was then reduced with stannous chloride $\left(\mathrm{SnCl}_{2}\right)$ to convert $\mathrm{Hg}$ (II) to volatile $\mathrm{Hg}(0)$. $\mathrm{The} \mathrm{Hg}(0)$ was purged from the sample aliquot with $\mathrm{N}_{2}$ gas onto a gold coated glass bead trap. Mercury was thermally desorbed from the sample trap in an Argon gas stream and collected on a second gold trap (analytical trap), thermally desorbed from the analytical trap in the same gas stream and carried into the cell of a cold vapor atomic fluorescence spectrometer (CVAFS) for detection. The modification of this method for particulate samples consisted of transferring the filter from the petri dish to a Teflon bottle and adding $100 \mathrm{~mL}$ of $5 \% \mathrm{BrCl}$ in reagent water. The particulate samples were then treated as water samples. This modification can be used to determine $\mathrm{THg}$ concentrations in particulate samples with a method detection limit (MDL) of $0.060 \mathrm{ng}$ of mercury on a filter. The amount of mercury on a filter is dependant on the sediment load in the sample and volume of sample 
filtered. Methylmercury analyses were performed using USGS method numbers I-1045-02 (filtered water) and I-3045-02 (unfiltered water) (DeWild et al. 2002) with slight modifications for particulate samples (http://pubs. water.usgs.gov/tm5A7/). Water samples were distilled to remove potential matrix interferences. The $\mathrm{pH}$ of the distillate was adjusted to 4.9 (to maximize ethylation potential) using acetate buffer. The distillate then was ethylated using sodium tetraethyl borate $\left(\mathrm{NaBEt}_{4}\right)$ and allowed to react for $15 \mathrm{~min}$. After reaction with $\mathrm{NaBEt} 4$, the distillate was purged with nitrogen gas $\left(\mathrm{N}_{2}\right)$ for $20 \mathrm{~min}$ and the ethylated mercury species were collected on a sample trap containing Carbotrap. These ethylated mercury species were desorbed thermally from the sample trap, separated using a gas chromatographic (GC) column, reduced using a pyrolytic column, and detected using a cold vapor atomic fluorescence spectrometry (CVAFS) detector. Particulate samples were distilled by adding $50 \mathrm{~mL}$ of reagent grade water and $2 \mathrm{~mL}$ of a combined reagent consisting of $20 \% \mathrm{KCl}, 50 \% \mathrm{H}_{2} \mathrm{SO} 4$, and $1 \mathrm{M} \mathrm{CuSO}_{4}$ in a ratio of 1:2:2. The distillates were then treated as water samples for detection. This modification can be used to determine methyl mercury concentrations in particulate samples with a method detection limit of $0.010 \mathrm{ng}$ of mercury on a filter. The amount of mercury on a filter is dependant on the sediment load in the sample and volume of sample filtered.

\section{Methylmercury Production/Degradation Studies}

In situ measurements of $\mathrm{pH}$, redox, and temperature were made at the sample location as described in Marvin-DiPasquale et al. (2003) (see further readings). Clean hands protocols and acid-cleaned stainless steel tools were used during sample collection. $\mathrm{MeHg}$ production potentials are defined in this study as the product of [the total ${ }^{203} \mathrm{Hg}$ (II) radiotracer amendment added $\mathrm{x}$ fraction of ${ }^{203} \mathrm{Hg}$ (II) radiotracer converted to me ${ }^{203} \mathrm{Hg}$ ], normalized per day and per gram of wet sediment. Similarly, $\mathrm{MeHg}$ degradation potentials are defined as the product of [the total ${ }^{14} \mathrm{CH}_{3} \mathrm{Hg}$ radiotracer amendment added $\mathrm{x}$ fraction of the ${ }^{14} \mathrm{CH}_{3} \mathrm{Hg}$ radiotracer degraded to ${ }^{14} \mathrm{CH}_{4}+{ }^{14} \mathrm{CO}_{2}$ ], normalized per day and per gram of wet sediment. Descriptions of meHg production and degradation potential rate assays are given elsewhere (Marvin-DiPasquale and Agee 2003; MarvinDiPasquale et al. 2003) (see further readings).
Briefly, all sediment was initially homogenized and sub-sampled in an anoxic ( $\mathrm{N}_{2}$ flushed) glove bag. Rates of microbial SR, $\mathrm{Hg}(\mathrm{II})$-methylation and $\mathrm{MeHg}$ degradation were measured in parallel sample sets using the ${ }^{203} \mathrm{HgCl}_{2}$, and ${ }^{14} \mathrm{CH}_{3} \mathrm{HgCl}$ radiolabel techniques, respectively. Specific activities of the injection solutions [April 2002-July 2003] were 0.70-0.84 and $0.30 \mathrm{mCi} / \mathrm{mg}$ (as $\mathrm{Hg}$ ), respectively. Radiotracer solution amendments of 1,000-1,225 nCi (per $0.1 \mathrm{~mL}$ ) of ${ }^{203} \mathrm{HgCl}_{2}$ and $9.8-10.1 \mathrm{nCi}$ (per $0.1 \mathrm{~mL}$ ) of ${ }^{14} \mathrm{CH}_{3} \mathrm{HgCl}$, into $3.0 \mathrm{~g}$ of sediment per sample, resulted in final amendment concentrations of 475$489 \mathrm{ng} \mathrm{Hg}(\mathrm{II})$ per $\mathrm{g}$ wet sediment and 10.9-11.2 ng $\mathrm{CH}_{3} \mathrm{Hg}^{+}$(as $\mathrm{Hg}$ ) per $\mathrm{g}$ wet sediment, respectively. These values generally exceed the in situ sediment $\mathrm{HgT}\left(8-100 \mathrm{ng} / \mathrm{g}\right.$ wet sediment) and $\mathrm{meHg}\left(0.08_{-}\right.$ $3.2 \mathrm{ng} / \mathrm{g}$ wet sediment) concentrations, and thus cannot be considered true tracer assays. Rate constants for each $\mathrm{MeHg}$ production were calculated as the fraction of the ${ }^{203} \mathrm{Hg}$ (II) isotope converted to $\mathrm{Me}^{203} \mathrm{Hg}$ during the $23-24 \mathrm{~h}$ incubation period. Radioactivity in incubated samples was corrected for carry-over of unreacted $203 \mathrm{Hg}$ (II) in the organic extraction of $\mathrm{Me}^{203} \mathrm{Hg}$, by subtracting the activity in killed controls that were similarly amended but not incubated. Potential rates of meHg production and degradation were then calculated as a function of the radiotracer derived rate constants and the original amendment concentration, assuming psuedo-first order kinetics (Marvin-DiPasquale et al. 2003) (see further readings).

\section{Quality Assurance}

Concentrations of major ions, DOC, POC, DHg, $\mathrm{PHg}$ and other trace metals in blanks processed at the on-site lab were below detection limits, indicating a clean sample-processing environment. Differences in concentrations measured in field replicates were less than $10 \%$ for DOC and $\mathrm{DHg}$, and less then $20 \%$ for $\mathrm{POC}$ and $\mathrm{PHg}$ indicating acceptable reproducibility. Differences in concentrations measured in laboratory duplicates were less than $10 \%$ indicating high analytical precision. An inter-laboratory comparison for DHg and PHg showed that the difference between replicates was about the same as the difference between laboratories (approximately $0.3 \mathrm{ng} / \mathrm{L}$ ). Moreover, a paired $T$-test indicated no significant difference in $\mathrm{Hg}$ concentrations between laboratories $(p<0.05)$. The method for determination of $\mathrm{PmeHg}$ produced 
detection limits as low as $0.001 \mathrm{ng} / \mathrm{L}$, where as the detection limit for $\mathrm{DmeHg}$ was much greater (0.04 ng/L) (Olson and DeWild 1999). Because of these substantial differences in detection limits, only PmeHg could be used in ratios to THg to avoid large errors in uncertainty.

\section{References}

Aastrup, M., \& Johnson, J. (1991). Occurrence and transport of mercury within a small catchment area. Water, Air and Soil Pollution, 56, 155-167.

Allan, C. J., Heyes, A., Roulet, N. T., St Louis, V. L., \& Rudd, J. W. M. (2001). Spatial and temporal dynamics of mercury in Precambrian Shield upland runoff. Biogeochemistry, 52, 13-40.

Balogh, S. J., Meyer, M. L., Hansen, N. C., Moncrief, J. F., \& Gupta, S. C. (2000). Transport of mercury from a cultivated field during snowmelt. Journal of Environmental Quality, 29(3), 871-874.

Benoit, J. M., Gilmour, C. C., Heyes, A., \& Miller, C. L. (2003). Geochemical and biological controls over methylmercury production and degradation in aquatic systems. ACS Symposium Series, 835, 262-297.

Benoit, J. M., Gilmour, C. C., \& Mason, R. P. (2001b). Aspects of bioavailability of mercury for methylation pure cultures of Desulfobulbus propionicus (1pr3). Applied and Environmental Microbiology, 67(1), 51-58.

Benoit, J. M., Mason, R. P., Gilmour, C. C., \& Aiken, G. R. (2001a). Constants for mercury binding by dissolved organic matter isolates from Florida Everglades. Geochimica et Cosmochimica Acta, 65(24), 4445-4451.

Bishop, K., Lee, Y. H., Pettersson, C., \& Allard, B. (1995a). Methylmercury in runoff from the Svartberget Catchment in northern Sweden during a stormflow episode. Water, Air and Soil Pollution, 80, 1-4.

Bishop, K., Lee, Y. H., Pettersson, C., \& Allard, B. (1995b). Terrestrial sources of methylmercury in surface waters: The importance of the riparian zone on the Svartberget Catchment. Water, Air and Soil Pollution, 80, 1-4.

Bishop, K., Lee, Y. H., Pettersson, C., \& Allard, B. (1995c). Methylmercury output from the Svartberget Catchment in northern Sweden during spring flood. Water, Air and Soil Pollution, 80, 1-4.

Cowell, S. E., Hurley, J. P., Shafer, M. M., \& Hughes, P. E. (1995). Mercury partitioning and transport in Lake Michigan tributaries. International Association for Great lakes Research, 88 p.

David, M. B., \& Vance, G. F. (1991). Chemical character and origin of organic acids in streams and seepage lakes of central Maine. Biogeochemistry, 12, 17-41.

DiPasquale, M. C., Agee, J. L., Bouse, R. M., \& Jaffe, B. E. (2003). Microbial cycling of mercury in contaminated pelagic and wetland sediments of San Pablo Bay, California. Environmental Geology, 43, 260-267.
Driscoll, C. T., Blette, V., Yan, C., Scholfield, C. L., Munson, R., \& Holsapple, J. (1995). The role of dissolved organic carbon in the chemistry and bioavailability of mercury in remote Adirondack lakes. Water, Air and Soil Pollution, 80, 499 508.

Driscoll, C. T., Driscoll, K. M., Mitchell, M. J., \& Raynal, D. J. (2003). Effects of acidic deposition on forest and aquatic ecosystems in New York State. Environmental Pollution, 123(3), 327-336.

Fitzgerald, W. F., Engstrom, D. R., Mason, R. P., \& Nater, E. A. (1998). The case for atmospheric mercury contamination in remote areas. Environmental Science \& Technology, 32, 1-7.

Fleck, J. A. (1999) Mercury transport through northern forested watersheds: Dissolved and particulate pathways. M.S. Thesis, St. Paul, Minnesota: University of Minnesota.

Gilmour, C. C., Riedel, G. S., Ederington, J. T., Bell, J. T., Benoit, J. M., Gill, G. A., et al. (1998). Methymercury concentrations and production rates across a trophic gradient in the northern Everglades. Biogeochemistry, 40, 327-345.

Grigal, D. F. (2002). Inputs and outputs of mercury from terrestrial watersheds: A review. Environmental Review, 10, 1-39.

Haitzer, M., Aiken, G. R., \& Ryan, J. N. (2002). Binding of mercury (II) to dissolved organic matter. The role of the mercury-to-DOM concentration ratio. Environmental Science and Technology, 36, 3564-3570.

Hongve, D. (1999). Production of dissolved organic carbon in forested catchments. Journal of Hydrology, 224, 3-4.

Hornbeck, J. W., Bailey, S. W., Buso, D. C., \& Shanley, J. B. (1997). Streamwater chemistry and nutrient budgets for forested watersheds in New England: Variability and management implications. Forest Ecology and Management, 93, 73-89.

Horowitz, A. J., Demas, C. R., Fitzgerald, K. K., Miller, T. L., \& Ricket, D. A. (1994). U.S. Geological Survey protocol for the collection and processing of surface-water samples for the subsequent determination of inorganic constituents in filtered water. U.S. Geological Survey, OF 94-0539, 57 p.

Hurley, J. P., Benoit, J. M., Babiarz, C. L., Shafer, M. M., Andren, A. W., Sullivan, J. R., et al. (1995). Influences of watershed characteristics on mercury levels in Wisconsin rivers. Environmental Science and Technology, 29, 1867-1875.

Hurley, J. P., Krabbenhoft, D. P., Cleckner, L. B., Olson, M. L., Aiken, G. R., \& Rawlik, P. S., Jr. (1998). System controls on the aqueous distribution of mercury in the northern Florida Everglades. Biogeochemistry, 40, 293-310.

Keefe, C. W. (1994). The contribution of inorganic compounds to the particulate carbon, nitrogen and phosphorus in suspended matter and surface sediments of Chesapeake Bay. Estuaries, 17, 122-130.

Krabbenhoft, D. P., Benoit, J. M., Babiarz, C. L., Hurley, J. P., \& Andren, A. W. (1995). Mercury cycling in the Allequash Creek Watershed, northern Wisconsin. Water, Air and Soil Pollution, 80, 425-433.

Lee, Y. H., Bishop, K., Pettersson, C., Iverfeldt, A., \& Allard, B. (1995a). Subcatchment output of mercury and methylmercury at Svartberget in northern Sweden. Water, Air and Soil Pollution, 80, 1-4. 
Lee, Y. H., Bishop, K., Hultberg, H., Pettersson, C., Iverfeldt, A., \& Allard, B. (1995b). Output of methylmercury from a catchment in northern Sweden. Water, Air and Soil Pollution, 80, 1-4.

Lee, Y. H., Bishop, K. H., \& Munthe, J. (2000). Do concepts about catchment cycling of methymercury and mercury in boreal catchments stand the test of time? Six years of atmospheric inputs and runoff export at Svartberget, northern Sweden. Science of the Total Environment, 260, 11-20.

Marvin-DiPasquale, M., \& Agee, J. L. (2003). Microbial cycling in sediments of the San Francisco Bay-Delta. Estuaries, 26(6), 1517-1528.

Mattsson, T., Kortelainen, P., \& David, M. B. (1998). Dissolved organic carbon fractions in Finnish and Maine (USA) lakes. Environment International, 24(5/6), 521-525.

Maurice-Bourgoin, L., Quemerais, B., Moreira-Turcq, P., \& Seyler, P. (2003). Transport, distribution and speciation of mercury in the Amazon River at the confluence of black and white waters of the Negro and Solimos Rivers. Hydrological Processes, 17(7), 1405-1417.

McCall, R. B. (1986). Fundamental statistics for behavioral sciences, 4th ed., p. 439. Harcourt Brace Jovanovich, Inc, Publisher.

McDonnell, J. J., McGlynn, B. L., \& Kendall, K. (1998, April). The role of near-sream riparian zones in the hydrology of stepp upland catchments, Hydrology, Water Resources and Ecology in Headwaters. (Paper presented at the Proceedings of the HeadWater '98 conference, Meran, Italy, IAHS Publ. no. 248).

McGlynn, B. L., McDonnell, J. J., Shanley, J. B., \& Kendall, C. (1999). Riparian zone flowpath dynamics during snowmelt in a small headwater catchment. Journal of Hydrology, 222, 75-92.

Moore, T. R. (2003). Dissolved organic carbon in a northern boreal landscape. Global Biogeochemical Cycles, 17(4), 8.

Morel, F. M. M., Kraepiel, A. M. L., \& Amyot, M. (1998). The chemical cycle and bioaccumulation of mercury. Annual Review of Ecology and Systematics, 29, 543-566.

Munthe, J., Hultberg, H., Lee, Y. H., Parkman, H., Iverfeldt, A., \& Renberg, I. (1995). Trends of mercury and methylmercury in deposition, run-off water and sediments in relation to experimental manipulations and acidification. Water, Air, and Soil Pollution, 85(2), 743-748.

Peters, N. E., Shanley, J. B., Aulenbach, B. T., Webb, R. M., Campbell, D. H., Hunt, R., et al. (2006). Water and solute mass balance of five small, relatively undisturbed watersheds in the U.S. Science of the Total Environment, 358, 221-242.

Rasmussen, P. E. (1995). Temporal variation of mercury in vegetation. Water, Air and Soil Pollution, 80, 1039-1042.

Ravichandran, M. (2004). Interactions between mercury and dissolved organic matter: A review. Chemosphere, 55, 319-331.

Reddy, M. M., \& Aiken, G. R. (2001). Fulvic acid-sulfide ion competition for mercury ion binding in the Florida Everglades. Water, Air, and Soil Pollution, 132, 89-104.

Rudd, J. W. M. (1995). Sources of methyl mercury to freshwater ecosystems: A review. Water, Air and Soil Pollution, 80, 1-4.
Sakamoto, H. E., Cleckner, L. B., Hurley, J. P., Rolfhus, K. R., Keeler, G. J., Armstrong, D. E., et al. (2001, June). Atmospheric methyl mercury loading in the Lake Superior Basin, (Paper presented at the 44th Conference on Great Lakes Research, Great Lakes Science: Making it Relevant), 116-117.

Scherbatskoy, T., Shanley, J. B., \& Keeler, G. J. (1998). Factors controlling mercury transport in an upland forested catchment. Water, Air, and Soil Pollution, 105, 427-438.

Schwesig, D., Ilgen, G., \& Matzner, E. (1999). Mercury and methymercury in upland and wetland acid forest soils of a watershed in NE-Bavaria, Germany. Water, Air, Soil Pollution, 113, 141-154.

Shanley, J. B., \& Chalmers, A. (1999). The effect of frozen soil on snowmelt runoff at Sleepers River, Vermont. Hydrological Processes, 13, 12-13.

Shanley, J. B., Donlon, A. F., Scherbatskoy, T., \& Keeler, G. R. (1999) Mercury cycling and transport in the Lake Champlain Basin, in T.O. Manley, and P.L. Manley, eds., Lake Champlain in transition: From research toward restoration: American Geophysical Union. Water Science and Application, 1, 227-299

Shanley, J. B., Kendall, C., Albert, M. R., \& Hardy, J. P. (1995). Chemical isotopic evolution of a layered eastern U.S. snowpack and its relation to stream-water composition. Biogeochemistry of Seasonally Snow-Covered Catchments, 228, 329-338.

Shanley, J. B., Schuster, P. F., Reddy, M. M., Roth, D. A., Taylor, H. E., \& Aiken, G. R. (2002). Mercury on the move during snowmelt in Vermont. EOS Transactions, 83(5), 45-48.

Skyllberg, U., Quin, J., French, W., Xia, K., \& Bleam, W. F. (2003). Distribution of mercury, methymercury and organic sulfur species in soil, soil solution and stream of a boreal forest catchment. Biogeochemistry, 64, 5376.

Skyllberg, U., Xia, K., Bloom, P., Nater, E. A., \& Bleam, W. F. (2000). Binding of mercury(II) to reduce sulfur in soil organic matter along upland peat soil transects. Journal of Environmental Quality, 29(3), 855-865.

Ussiri, D. A., \& Johnson, C. E. (2004). Sorption of organic carbon fractions by Spodosol mineral horizons. Soil Science Society of America Journal, 68(1), 253-262.

USEPA (1994). Method 7471A, Revision 1: Mercury in solid or semisolid waste: EPA SW-846, 7 p.

USEPA (1997). Method No. 440.0 Determination of carbon and nitrogen in sediments and particulates of estuarine/ coastal waters using elemental analysis. Cincinnati, Ohio, September 1997.

Weishaar, J. L., Aiken, G. R., Bergamschi, B. A., Fram, M. S., Fujii, R., \& Mopper, K. (2003). Evaluation of specific ultraviolet absorbance as an indicator of the chemical composition and reactivity of dissolved organic carbon. Environmental Science and Technology, 37, 4702-4708

Wilde, F. D., Radtke, D. B., Gibs, J., Iwatsubo, R. T. (Eds.) (1998). National field manual for the collection of water quality data (In Techniques of Water-Resources 
Investigations, Book 9, handbooks of water resources investigations. Washington D.C.: U.S Geological Survey).

\section{Further Reading}

Aiken, G. R., McKnight, D. M., Thorn, K. A., \& Thurman, E. M. (1992). Isolation of hydrophilic organic acids from water using nonionic macroporous resins. Organic Geochemistry, $18,567-573$.

Babiarz, C. L., Hoffmann, S. R., Shafer, M. M., Hurley, J. P., Andren, A. W., \& Armstrong, D. E. (2000). A critical evaluation of tangential-flow ultrafiltration for trace metal studies in freshwater systems. 2. Total mercury and methylmercury. Envrionmental Science and Technology, 34, 3428-3434.

Chin, Y. P., Aiken, G., \& Oloughlin, E. (1994). Molecular weight, polydispersity, and spectroscopic properties of aquatic humic substances. Envrionmental Science and Technology, 28, 1853-1858.

DeWild, J. F., Olson, M. L., \& Olund, S. D. (2002). Determination of methyl mercury by aqueous phase ethylation, followed by gas chromatographic separation with cold vapor atomic flourescence detection. U.S. Geological Survey Open-File Report 01-445, 14.

DeWild, J. F., Olund, S. D., Olson, M. L., \& Tate, M. T. (2004). Methods for the preparation and analysis of solids and suspended solids for methymercury. U.S. Geological Survey Techniques and Methods, Chapter A7, Book 5, 21.
Fishman, M. J., \& Friedman, L. C. (1989). Methods for determination of inorganic substances in water and fluvial sediments, Techniques of Water-Resources Investigations, Chapter A1, Book 5, handbooks of water resources investigations (p. 466). Washington D.C.: U.S Geological Survey.

Kelly, T., \& Taylor, H. E. (1996). Concentrations and loads of selected trace elements and other constituents in the Rio Grande in the vicinity of Albuquerque, New Mexico, 1994. U.S. Geological Survey Open-File Report 96-0126, 45.

Marvin-DiPasquale, M. C., Agee, J. L., Bouse, R. M., \& Jaffe, B. E. (2003). Microbial cycling of mercury in contaminated pelagic and wetland sediments of San Pablo Bay, California. Environmental Geology, 43, 260-267.

Olson, M. L., \& DeWild, J. F. (1999) Techniques for the collection and species-specific analysis of low levels of mercury in water, sediment, and biota: Water Resources Investigations 99-4018-B, 11.

Olund, S. D., DeWild, J. F., Olson, M. L., \& Tate, M. T. (2004). Methods for the preparation and analysis of solids and suspended solids for total mercury. U.S. Geological Survey Techniques and Methods, Chapter A8, Book 5, 23.

Roth, D. A. (1994). Ultratrace analysis of mercury and its distribution in some natural waters in the United States. Dissertation. Ft. Collins: Colorado State University.

USEPA (1996). Method No. 1631, Mercury in Water/Oxidation, Purge and Trap, CFAFS, 821/R-96-012. 